\title{
Modelling the impact of aquaculture on early diagenetic processes in sea loch sediments
}

\author{
Daniele Brigolin ${ }^{1, *}$, Roberto Pastres ${ }^{1}$, Thomas D. Nickell ${ }^{2}$, Chris J. Cromey ${ }^{2}$, \\ David R. Aguilera ${ }^{3,4}$, Pierre Regnier ${ }^{4,5}$ \\ ${ }^{1}$ Department of Physical-Chemistry, University of Venice, Calle Larga S.Marta 2137, 30123 Venice, Italy \\ ${ }^{2}$ Scottish Association for Marine Science, Dunstaffnage Marine Laboratory, Oban, Argyll PA37 1QA, UK \\ ${ }^{3}$ DELTARES-TNO Built Environment and Geosciences, Dept. Groundwater quality, Princetonlaan 6, 3508 TA Utrecht, \\ The Netherlands \\ ${ }^{4}$ Department of Earth Sciences, Utrecht University, PO Box 80.021, 3508 TA Utrecht, The Netherlands \\ ${ }^{5}$ Department of Earth and Environmental Sciences, CP 160/02, Université Libre de Bruxelles, 50 Av. F. D. Roosevelt, \\ 1050 Brussels, Belgium
}

\begin{abstract}
We present a novel approach for the simulation of the impacts of finfish aquaculture on sedimentary redox dynamics, based on the coupling of a fish farm waste deposition model (DEPOMOD) and a knowledge-based reactive transport model (RTM) of early diagenesis. The integrated model was applied to a salmon fish farm located in a Scottish fjordic sealoch. The major diagenetic processes of the reaction network were first identified on the basis of literature information and historic data. Next, the organic carbon (OC) flux at a pristine site near the farm was estimated by fitting the vertical profiles of pore water and solid-state chemical species measured in the field. DEPOMOD was then used to predict the fluxes of OC due to the release of uneaten feed and faeces at various distances away from the farm. These fluxes were added to the background 'natural' fluxes and used as forcing functions for the RTM. Comparison of the simulated transient profiles with data collected at an impacted site revealed that the RTM model satisfactorily predicted the transient dynamics of the system. We discuss the use of the model for cost-effective environmental impact assessments, site selection and the optimization of husbandry practices.
\end{abstract}

KEY WORDS: RTM - DEPOMOD $\cdot$ Transient simulation $\cdot$ Loch Creran $\cdot$ Atlantic salmon $\cdot$ Benthic mineralization

\section{INTRODUCTION}

In the last decade, an increasing availability of surficial marine sediment datasets (including pore water and solid-phase chemistry data) stimulated the development of complex reaction-transport numerical models (RTM) of early diagenesis. These models offer a realistic representation of sediment biogeochemistry (e.g. Berg et al. 2003, Jourabchi et al. 2005, Thullner et al. 2005, Dale et al. 2008a) and are particularly suitable to simulate the vertical redox zonation coupled to the process of organic carbon (OC) oxidation, which is controlled by the availability of electron acceptors and the Gibbs free energy associated with each metabolic pathway (Morel \& Hering 1993). Moreover, the inclusion in the reaction network of re-oxidation processes of the reduced compounds produced during OC decomposition, as well as an accurate parameterization of diffusion and advection processes, enables the unravelling of sedimentary cycles and fluxes of redoxsensitive species (Thuller et al. 2007).

In addition, the recent development of user-friendly RTM codes (Regnier et al. 2002, 2003, Meysman et al. 2003a,b, Aguilera et al. 2005) has stimulated their use by an expanding scientific community. So far, however, early diagenetic numerical models were cali- 
brated and/or tested by comparing model outputs at steady state with rate and concentration profiles observed in sediment (Thullner et al. 2005), whereas little work has been done on analysing the performances of these models in reproducing transient states, responding to time- or space-variable forcing conditions (e.g. Soetaert et al. 1996, Luff \& Wallmann 2003, Dale et al. 2008a,b). From a methodo- logical standpoint, this analysis can be regarded as a test for evaluating model robustness (sensu Gribble 2001), i.e. the ability of a system to continue to operate correctly across a wide range of operating conditions.

The application of early diagenesic models to predict changes in geochemical cycles due to anthropogenic perturbations are limited (e.g. Canavan et al. 2006). From this perspective, aquaculture site selection and monitoring represent potential new areas of application for RTMs. As the human population continues to expand, its reliance on farmed fish production as a source of protein is expected to increase (Naylor et al. 2000), in turn increasing the demand for aquatic resources. However, further sustainable development of aquaculture requires a careful assessment of their impacts, not only on pelagic ecosystems, but also on the benthic environment (Black 2001).

The need to forecast and monitor organic enrichment resulting from intensive marine aquaculture has led to the development of numerical models that provide an estimate of the response of the macrobenthic community to increased OC rain (Cromey et al. 2002a). In these models, the representation of the impact of aquaculture is based on empirical correlations between OC fluxes and macrobenthic community indices. However, recent work indicates that geochemical measures perform better than methods based on macrofaunal community analysis due to their cost-effectiveness; this has consequently increased the interest in early diagenesic studies (Hargrave et al. 1997, Wildish et al. 1999,
2001). In this regard, early diagenesic models could be used for the mechanistic simulation of the impacts of aquaculture on geochemical processes.

In the present work, a RTM of early diagenesis is applied to simulate the concentration profiles of redox species in sediments of a fjordic sea loch, at sites which were exposed to high $\mathrm{OC}$ fluxes from aquaculture. The model was first calibrated on pore water and sediment chemistry data collected at a pristine site under steadystate conditions. Secondly, the steady-state boundary conditions were perturbed by adding the fish farmderived OC rain calculated by a particle-tracking model (DEPOMOD). Simulations were then performed to analyse the model response to the establishment of a new fish farm, and the transient profiles predicted by the model were compared with field data. The evaluation of the performance of the coupled models (DEPOMOD + RTM) was part of a larger EU research initiative focused on the development and testing of numerical models for aquaculture site selection and monitoring (www.ecasa.org.uk).

\section{MATERIALS AND METHODS}

Study site and field data description. Loch Creran is a fjordic sea loch located on the west coast of Scotland, with a surface area of approximately $10 \mathrm{~km}^{2}$ and a maximum depth of $50 \mathrm{~m}$ (Fig. 1). The mean freshwater input is $286 \times 10^{6} \mathrm{~m}^{3} \mathrm{yr}^{-1}$, and it has a relatively short flushing time of 3 d (Edwards \& Sharples 1986). The loch has 4 main basins separated by narrow sills; the study site is located in a basin that is $9 \mathrm{~km}$ long and has a maximum depth of $49 \mathrm{~m}$. The loch is relatively sheltered from wave action and has a freshwater runoff of $286 \times 10^{6} \mathrm{~m}^{3} \mathrm{yr}^{-1}$. The important topographical features of Loch Creran are the 2 sills between the farm location and the fully marine Firth of Lorne. These sills have

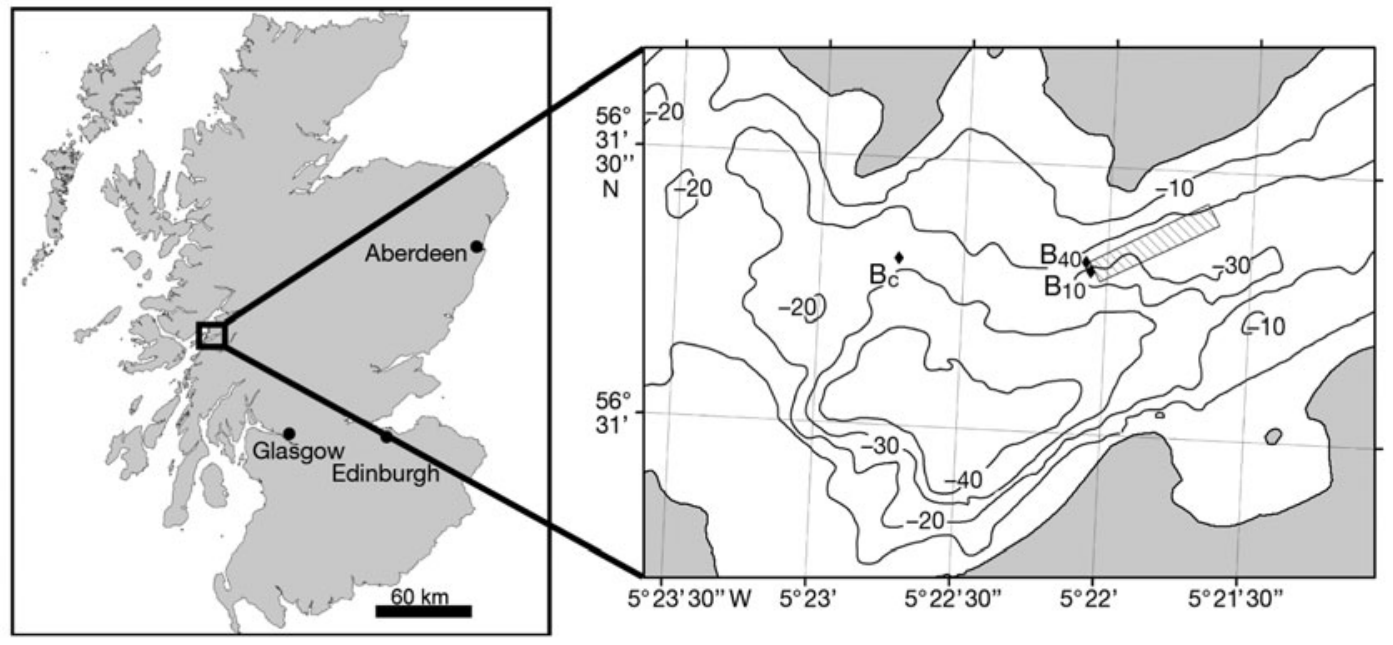

Fig. 1. Map of Scotland showing a portion of Loch Creran with sampling stations (»), bathymetry (in $\mathrm{m}$ ) and fish farm location (MII) ) 
depths of 7 and $11 \mathrm{~m}$, with deeper water on either side of them. Despite these topographic features, the site location is reasonably well flushed, with a flushing time of $3 \mathrm{~d}$ and a moderate current. The loch can be thermally and/or salinity stratified depending on season and rainfall. For a detailed description of the loch's morphology, cf. Tett \& Wallis (1978) and Edwards \& Sharples (1986). Salmon farming has been practiced in this loch for $>10 \mathrm{yr}$, and fish cages are periodically re-sited to minimise environmental impacts and allow benthic recovery. The area sampled in the present study was impacted by organic deposits from a salmon farm that had been established in March 2006. The farm has a maximum consented biomass of $1.5 \times 10^{6} \mathrm{~kg} \mathrm{yr}^{-1}$. Atlantic salmon Salmo salar are reared in 6 circular net cages of $22 \mathrm{~m}$ diameter, with a net depth of $14 \mathrm{~m}$.

A detailed biogeochemical survey was carried out at 3 stations, in order to calibrate/validate the early diagenesis model. Station location, cage arrangement and bathymetry of the area are depicted in Fig. 1. Samples were collected on 17 August 2006, approximately 6 mo after the establishment of the fish farm. Three stations were sampled: $B_{10}$, situated $10 \mathrm{~m}$ from the edge of the cage; $B_{40}$, away from the cage, but still within the depositional footprint; and $\mathrm{B}_{\mathrm{C}}$, a non-impacted control site. Samples were collected from RV 'Calanus' using a Bowers \& Connelly megacorer (core i.d. = $100 \mathrm{~mm}$; Barnett et al. 1984). Nickell et al. (2003) reported the results from a video survey, characterising this area of Loch Creran as soft and muddy sediments.

Cores were placed in stands and kept under running seawater until returned to the laboratory. The following day, each $10 \mathrm{~cm}$ long sediment core was sliced into $1 \mathrm{~cm}$ layers in a glove bag under nitrogen and maintained at $4^{\circ} \mathrm{C}$, in order to obtain high resolution data for each chemical variable. Slices sub-sampled for OC and total phosphorous were kept frozen at $-20^{\circ} \mathrm{C}$; pore water was extracted by centrifuging slices obtained under nitrogen, and kept refrigerated $\left(4^{\circ} \mathrm{C}\right)$ for analysis. Porosity was determined by weighing wet sediment, freeze drying and re-weighing. The spectrophotometric analysis of pore water ammonia was based on the standard Berthelot method adapted by O'Dell (1993). The analysis of total (inorganic and organic) phosphorus in the sediment was based on the classic molybdate/ascorbic acid and spectrophotometric method described by Strickland \& Parsons (1972), with modification by Aspila et al. (1976). Organic carbon (CHN) samples were lyophilised, ground and acidified to remove inOC (Tung \& Tanner 2003) prior to analysis with a LECO CHN-900 auto analyser (LECO Corporation). For pore water sulphate determination, aliquots of the samples were diluted 100 times, and sulphate was measured on a Dionex System 14 ion chromatograph (Dionex Corporation) with an AG4A guard column, an AS4A separator column and suppressed conductivity detection. A calibration line was constructed using known concentrations of a standard sulphate solution, from which the concentrations of the samples were determined (S. M. Harvey pers. comm.). Iron and manganese concentrations in pore water were determined using a PE 4300DV inductively coupled plasma-atomic emission spectrometer (Perkin Elmer Life \& Analytical Sciences, Inc.). Calibrations were prepared from commercially available singleelement standard solutions (CPI International) and were matrix matched to seawater with respect to sodium, potassium, calcium, magnesium and strontium. Pore water solutions were diluted by a factor of 20 in $5 \% \mathrm{v} / \mathrm{v}$ nitric acid solution and determined in axial mode.

Model description. The benthic-pelagic exchange was simulated using 2 models (Fig. 2):

(1) A particle-tracking and resuspension model, DEPOMOD (Cromey et al. 2002a), which predicts the flux of organic matter (OM) to the seabed due to the release of waste food and faeces; and

(2) A 1-dimensional early diagenesis model, hereafter termed EDM, implemented by means of the biogeochemical reaction network simulator (BRNS) (Regnier et al. 2003, Aguilera et al. 2005).

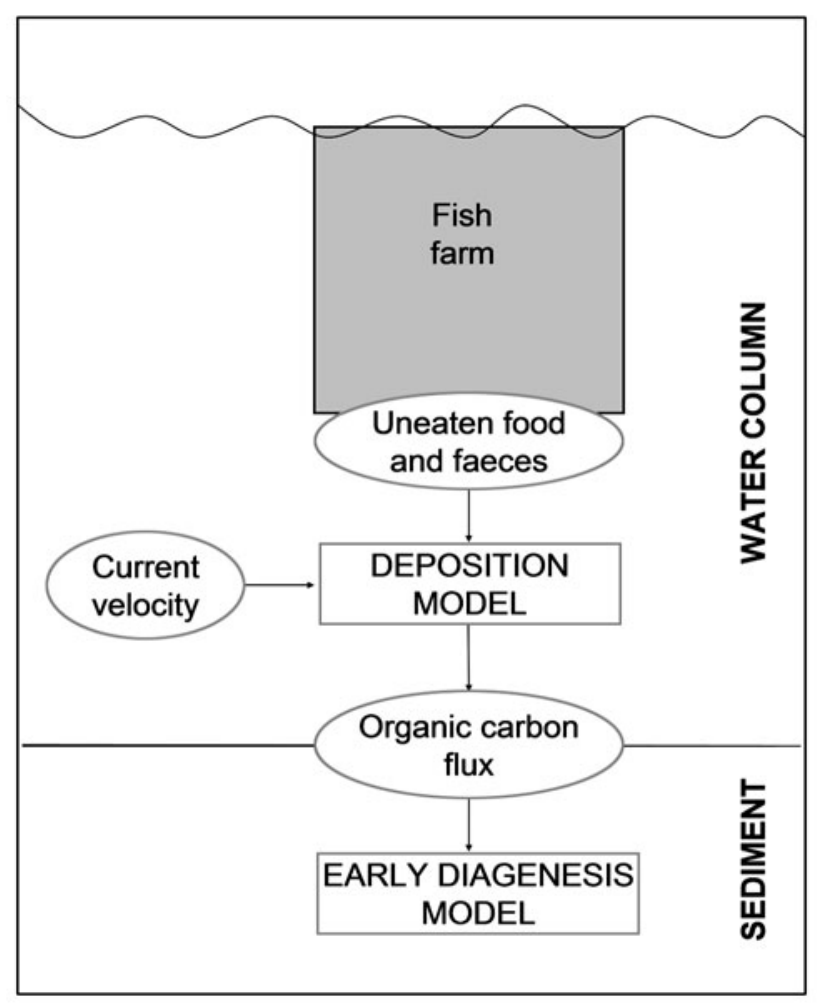

Fig. 2. Schematic representation of the integrated numerical models 
The DEPOMOD-derived flux of OC from uneaten food and faeces released by the fish farm provides the boundary condition for the EDM.

The set up of the 2 coupled models involved 4 steps:

(1) The EDM was calibrated by comparing model output at steady state with the set of data collected at a site outside the fish farm deposition footprint ( $\operatorname{Stn} \mathrm{B}_{\mathrm{C}}$ ). This step provided an estimate of the background OC deposition fluxes;

(2) OC fluxes at 2 stations located near the fish farm were predicted by DEPOMOD (Stns $\mathrm{B}_{10}$ and $\mathrm{B}_{40}$ );

(3) OC fluxes predicted by DEPOMOD were added to the background fluxes, and the EDM was then run for the transient state;

(4) Transient profiles predicted by the model were compared with data collected at the 2 stations located near the fish farm.

The study of the transient diagenesis involved 2 simulations: Run 1 for the 'nominal' conditions and Run 2 for a sensitivity test, carried out by varying the OC flux at the boundary of the EDM.

Deposition model. DEPOMOD is a local-scale, 2-dimensional model, which applies a Lagrangian method to simulate particle movement throughout the water column. Particles were advected using as input time series of water velocity at different depths, either recorded using current meters or estimated by means of a hydrodynamic model. Turbulence was represented as a random walk. Resuspension was related to critical values of current velocity at the seabed (Cromey et al. 1998, 2002b). As an output, see Fig. 2, the model provided 2-dimensional maps of $\mathrm{OM}$ flux at the seabed. The model was validated for Scottish sea lochs (Cromey et al. 2002a,b) and is currently used for regulatory purposes by the Scottish Environment Protection Agency (www.sepa.org.uk).
DEPOMOD predictions of carbon flux at the sediment-water interface (SWI) were obtained using a time series of farmed fish biomass from March to August 2006 (average $40 \times 10^{3} \mathrm{~kg}$ ). Cage layout and husbandry data, provided by the fish farm company (www. scottishseafarms.com/), along with the other parameters used in the simulation are specified in Table 1. Hydrographic data had been collected at the site as part of regulatory requirements; summary statistics are presented in Table 2. All 3 meters (surface; mid-water; near-bed) showed residual water movement to the W-NW or SW, which is seaward. The residual is most pronounced on the surface layer due to freshwater runoff, and the tidal cycle is clearly defined with the nearbed meter, but less clear with the upper meters.

The carbon contents of feed and faeces were estimated on the basis of the references reported in Table 3. The water content of feed, usually set to the default value of $9 \%$ in DEPOMOD (Cromey et al. 2002a), was adjusted to $5.5 \%$, see references in Table 3. No information on digestibility was available, and the default value of $85 \%$ was thus used.

The loss of carbon mass between the surface and sea bed was accounted for by determining, from settling velocities and depth at the site $(27 \mathrm{~m})$, the time necessary for the feed $(5.4 \mathrm{~min})$ and faeces $(14.1 \mathrm{~min})$ to settle. Carbon accounted for $27.7 \%$ of faecal mass using the 10 min immersion time from Chen et al. (2003). A $3 \%$ mass loss of carbon was used for feed pellets for a pre-conditioning time of $0 \mathrm{~h}$ (Stewart \& Grant 2002). This represented an immediate loss in mass of the food pellet in the model and simulates loss of mass from dust and fragmentation.

Early diagenesic model. The EDM solves a set of partial differential equations (PDEs) describing the conservation of the mass of solid (Eq. 1) and dissolved

Table 1. Input data used for DEPOMOD model

\begin{tabular}{|c|c|c|}
\hline Input data & Loch Creran & Data source \\
\hline Grid cell size $(m)$ - square grid & 10 & - \\
\hline Number of cages & 6 & Farmer \\
\hline Number of current velocity data sets used & 3 & Provost (2001) \\
\hline Height of moorings above sea bed $(\mathrm{m})$ & $25 ; 14 ; 2$ & Provost (2001) \\
\hline Length of current velocity record (d); model time step (min) & $18 ; 60$ & Provost (2001) \\
\hline Specific feeding rate $\left(\mathrm{SFR}_{i} \%\right.$ biomass $\left.\mathrm{d}^{-1}\right)$ & 2.98 & Farmer \\
\hline Feed input $\left(\mathrm{kg} \mathrm{cage}^{-1} \mathrm{~d}^{-1}\right)$ : & 190 (average value Mar-Aug 2006) & Estimated using SFR and biomass \\
\hline Food settling velocity $\left(\mathrm{cm} \mathrm{s}^{-1} ;\right.$ mean; $\left.\mathrm{SD}\right)$ & Normal distribution $(8.3 ; 1.5)$ & DEPOMOD default value \\
\hline Faecal settling velocity $\left(\mathrm{cm} \mathrm{s}^{-1} ;\right.$ mean; SD) & Normal distribution $(3.2 ; 1.1)$ & DEPOMOD default value \\
\hline Dispersion coefficients $k_{x i} k_{y i} k_{z}\left(\mathrm{~m}^{2} \mathrm{~s}^{-1}\right)$ & $0.1 ; 0.1 ; 0.001$ & DEPOMOD default value \\
\hline Trajectory evaluation accuracy (s) & 60 & DEPOMOD default value \\
\hline
\end{tabular}


A fixed concentration was imposed at the upper boundary for all solutes, while a fixed flux was used for solids. A null-gradient condition was specified at the lower boundary for all chemical species. Even though the results presented here focus on the upper $10 \mathrm{~cm}$ layer, the physical domain of the model extended down to $40 \mathrm{~cm}$ depth, in order to minimise the computational artefacts generated from the null-gradient condition specified at the lower boundary. To our knowledge, no data on OM fluxes and reactive particulate Fe(III) and Mn(IV) fluxes at the upper boundary were available at our study site. These fluxes were therefore estimated during the calibration step, according to the strategy of inverse-use of the model proposed by van Cappellen \& Wang (1996) and Wang \& van Cappellen (1996) by minimising a goal function, $\Gamma$ :

$$
\Gamma=\sum_{i=1}^{n_{\mathrm{var}}} \sum_{j=1}^{n_{\text {obs }}}\left(\frac{\hat{\boldsymbol{x}}_{i, j}-\boldsymbol{x}_{i, j}}{\overline{\boldsymbol{x}}_{i}}\right)^{2}
$$

where $\hat{\boldsymbol{X}}_{i, j}$ and $\boldsymbol{x}_{i, j}$ are, respectively, predicted and observed concentrations for the $i$-variable at the $j$-depth. The weight, $\bar{x}$, was introduced in order to normalise the contributions of state variables characterised by different concentration ranges.

The RTM simulations were carried out by means of the BRNS, a flexible modelling environment for 1-dimensional simulation (Regnier et al. 2003, Aguilera et al. 2005). In the BRNS, spatial domain and transport coefficients, chemical species involved, reaction stoi- chiometries, and kinetic and equilibrium parameters are specified by the user through a web-based interface, which automatically generates a set of Fortran routines to solve the specified reaction-transport equation (Regnier et al. 2002, 2003, Aguilera et al. 2005). A detailed description of the mathematical formulation of the BRNS is given by Aguilera et al. (2005). Model outputs provide concentrations, reaction rates and fluxes at any grid point of the discretised spatial domain.

All reaction rate coefficients of the SRR, the limiting concentrations of electron acceptors involved in the primary redox reactions and the apparent equilibrium constant for FeS precipitation were based on those found in the literature (see Table 4). Site-specific parameters characterising the depositional environment were estimated on the basis of experimental information available for the study site. Their values, as well as the values of the parameters defining the physical domain, are listed in Table 5. According to Jourabchi et al. (2005), the bioturbation coefficient exponentially decreases with depth. The value at SWI and the depth of the mixed layer were fixed according to the experimental values measured by Nickell et al. (2003) at 2 non-impacted stations located in the vicinity of the fish farm studied in this work. Depth-dependent sediment porosity values were derived from the interpolation of field data collected here (Fig. 3). The average sediment density was estimated from a set of field data collected at different sites nearby the fish farm. Burial velocity was set in accordance with work by Loh et al. (2002)

Table 4. Reaction-specific parameters in the diagenesic model. 1: Sources-Wang \& van Cappellen (1996); 2: Jourabchi et al. (2005); 3: Canavan et al. (2006); 4: Berg et al. (2003)

\begin{tabular}{|c|c|c|c|c|}
\hline $\begin{array}{l}\text { Parameter } \\
\text { name }\end{array}$ & $\begin{array}{l}\text { Parameter } \\
\text { value }\end{array}$ & Units & Description & Source \\
\hline $\mathrm{O}_{2 \lim }$ & $16.0 \times 10^{-6}$ & $\mathrm{~mol} \mathrm{l}^{-1}$ & Limiting concentration for $\mathrm{O}_{2}$ & Mean value from $1,2,3,4$ \\
\hline $\mathrm{NO}_{3}^{-} \lim$ & $4.7 \times 10^{-6}$ & $\operatorname{mol~l} 1^{-1}$ & Limiting concentration for $\mathrm{NO}_{3}^{-}$ & Mean value from $1,2,3,4$ \\
\hline $\mathrm{MnO}_{2 \lim }$ & $13.3 \times 10^{-6}$ & $\mathrm{~mol} \mathrm{~g}^{-1}$ & Limiting concentration for $\mathrm{MnO}_{2}$ & Mean value from $1,2,3,4$ \\
\hline $\mathrm{Fe}(\mathrm{OH})_{3 \lim }$ & $87.0 \times 10^{-6}$ & $\mathrm{~mol} \mathrm{~g}^{-1}$ & Limiting concentration for $\mathrm{Fe}(\mathrm{OH})_{3}$ & Mean value from $1,2,3$ \\
\hline $\mathrm{SO}_{4}{ }^{2-} \lim$ & $1180.0 \times 10^{-6}$ & $\mathrm{~mol} \mathrm{l}^{-1}$ & Limiting concentration for $\mathrm{SO}_{4}^{2-}$ & Mean value from $1,2,3$ \\
\hline$k_{7}$ & $1.2 \times 10^{7}$ & $\left(\mathrm{~mol} \mathrm{l}^{-1}\right)^{-1} \mathrm{yr}^{-1}$ & Kinetic constant for nitrification & Mean value from $1,2,3,4$ \\
\hline$k_{8}$ & $3.3 \times 10^{8}$ & $\left(\mathrm{~mol} \mathrm{l}^{-1}\right)^{-1} \mathrm{yr}^{-1}$ & Kinetic constant for $\mathrm{Mn}^{2+}$ oxidation by $\mathrm{O}_{2}$ & Mean value from $1,2,3,4$ \\
\hline$k_{9}$ & $4.2 \times 10^{8}$ & $\left(\mathrm{~mol} \mathrm{l}^{-1}\right)^{-1} \mathrm{yr}^{-1}$ & Kinetic constant for $\mathrm{Fe}^{2+}$ oxidation by $\mathrm{O}_{2}$ & Mean value from $1,2,3,4$ \\
\hline$k_{10}$ & $3.7 \times 10^{7}$ & $\left(\mathrm{~mol} \mathrm{l}^{-1}\right)^{-1} \mathrm{yr}^{-1}$ & $\begin{array}{l}\text { Kinetic constant for } \mathrm{Fe}^{2+} \text { oxidation by } \mathrm{MnO}_{2} \\
\text { kinetic constant }\end{array}$ & Mean value from $1,2,3,4$ \\
\hline$k_{11}$ & $2.7 \times 10^{8}$ & $\left(\mathrm{~mol} \mathrm{l}^{-1}\right)^{-1} \mathrm{yr}^{-1}$ & $\begin{array}{l}\text { Kinetic constant for sulphides oxidation by } \\
\mathrm{O}_{2} \text { kinetic constant }\end{array}$ & Mean value from $1,2,3,4$ \\
\hline$k_{12}$ & $2.3 \times 10^{4}$ & $\left(\mathrm{~mol} \mathrm{l}^{-1}\right)^{-1} \mathrm{yr}^{-1}$ & $\begin{array}{l}\text { Kinetic constant for sulphides oxidation by } \\
\mathrm{MnO}_{2} \text { kinetic constant }\end{array}$ & Mean value from $1,2,3,4$ \\
\hline$k_{13}$ & $1.3 \times 10^{4}$ & $\left(\mathrm{~mol} \mathrm{l}^{-1}\right)^{-1} \mathrm{yr}^{-1}$ & $\begin{array}{l}\text { Kinetic constant for sulphides oxidation by } \\
\mathrm{Fe}(\mathrm{OH})_{3} \text { kinetic constant }\end{array}$ & Mean value from $1,2,3,4$ \\
\hline$k_{14}$ & $7.1 \times 10^{6}$ & $\left(\mathrm{~mol} \mathrm{l}^{-1}\right)^{-1} \mathrm{yr}^{-1}$ & $\begin{array}{l}\text { Kinetic constant for FeS oxidation by } \mathrm{O}_{2} \\
\text { kinetic constant }\end{array}$ & Mean value from $1,2,3,4$ \\
\hline$k_{15}$ & $1 \times 10^{10}$ & $\left(\mathrm{~mol} \mathrm{l}^{-1}\right)^{-1} \mathrm{yr}^{-1}$ & Kinetic constant for $\mathrm{CH}_{4}$ oxidation by $\mathrm{O}_{2}$ & Mean value from $1,2,3$ \\
\hline$k_{16}$ & $1 \times 10^{4}$ & $\left(\mathrm{~mol} \mathrm{l}^{-1}\right)^{-1} \mathrm{yr}^{-1}$ & Kinetic constant for $\mathrm{CH}_{4}$ oxidation by $\mathrm{SO}_{4}{ }^{2-}$ & Wang \& van Cappellen (1996) \\
\hline$k_{17}$ & $5 \times 10^{-6}$ & $\left(\mathrm{~mol} \mathrm{l}^{-1}\right) \mathrm{yr}^{-1}$ & Kinetic constant for FeS precipitation & Jourabchi et al. (2005) \\
\hline$K_{\mathrm{FeS}}$ & $6.3 \times 10^{-3}$ & & Apparent equilibrium constant for FeS precipitation & Jourabchi et al. (2005) \\
\hline
\end{tabular}


Table 5. Definition of model physical domain and site-specific parameters (from Table 4). The bioturbation coefficient is a function of depth, $z$, is in centimetres: $D_{\mathrm{b}}(z)=D_{\mathrm{b} 0} \cdot \mathrm{e}^{(-z / \lambda)}$. OM: organic matter; SWI: sediment-water interface

\begin{tabular}{|c|c|c|c|}
\hline Parameter & Value & Units & Reference \\
\hline $\mathrm{OM}_{1}$ rate constant, $k_{1}$ & 0.1 & $\mathrm{yr}^{-1}$ & $\begin{array}{l}\text { Derived from the Tromp et al. (1995) statistical model, } \\
\text { using a site-specific burial velocity }\end{array}$ \\
\hline $\mathrm{OM}_{2}$ rate constant, $k_{2}$ & 0.0 & $\mathrm{yr}^{-1}$ & - \\
\hline $\mathrm{OM}_{3}$ rate constant, $k_{3}$ & 1 & $\mathrm{yr}^{-1}$ & deBruyn \& Gobas (2004) \\
\hline Acceleration factor for oxic processes, $k_{\text {acc }}$ & 25 & - & Canavan et al. (2006) \\
\hline $\mathrm{C}: \mathrm{N}: \mathrm{P}_{\mathrm{OM} 1, \mathrm{OM} 2}$ & $80: 8: 1$ & & Ansell et al. (1974), Tett et al. (1985) \\
\hline $\mathrm{C}: \mathrm{N}: \mathrm{P}_{\mathrm{OM} 3}$ & $70: 8: 1$ & & $\begin{array}{l}\text { Stewart \& Grant (2002), deBruyn \& Gobas (2004), } \\
\text { Petersen et al. (2005) }\end{array}$ \\
\hline Sediment porosity at SWI, $\varphi_{0}$ & 0.76 & - & Present study \\
\hline Sediment porosity at $10 \mathrm{~cm}$ depth, $\varphi_{\infty}$ & 0.66 & & Present study \\
\hline Shape coefficient for porosity, $\tau$ & 0.3 & & Present study \\
\hline Sediment density & 1.43 & $\mathrm{~g} \mathrm{~cm}^{-3}$ & Harvey \& Phillips (1994), Dean (2004), SEPA (2005) \\
\hline Burial velocity, $\omega$ & 0.1 & $\mathrm{~cm} \mathrm{yr}^{-1}$ & Loh et al. (2002), Dean (2004) \\
\hline Bioturbation coefficient at SWI, $D_{\mathrm{b} 0}$ & 78 & $\mathrm{~cm}^{2} \mathrm{yr}^{-1}$ & Nickell et al. (2003) \\
\hline Attenuation coefficient, $\lambda$ & 1.5 & $\mathrm{~cm}$ & Nickell et al. (2003), Canavan et al. (2006) \\
\hline Temperature & 10.8 & ${ }^{\circ} \mathrm{C}$ & Present study \\
\hline Salinity & 33.0 & & Present study \\
\hline Time step & $5.0 \times 10^{-3}$ & $\mathrm{yr}$ & - \\
\hline Max. depth & 40 & $\mathrm{~cm}$ & - \\
\hline Number of nodes & 401 & - & - \\
\hline
\end{tabular}

and Dean (2004). The OM degradation rate constant $k_{1}$ $\left(0.1 \mathrm{yr}^{-1}\right)$ of the labile $\mathrm{OM}_{1}$ pool was determined by applying the global relationship proposed by Tromp et al. (1995). The value of the acceleration factor for aerobic decomposition, $k_{\text {acc }}$ was set in accordance with the value measured by Canavan et al. (2006) in a coastal freshwater lake. The ratio between the fluxes of $\mathrm{OM}_{1}$ and $\mathrm{OM}_{2}$ pools was set to $2: 1$, based on the evidence, reported by Loh et al. (2002), that Loch Creran sedi-

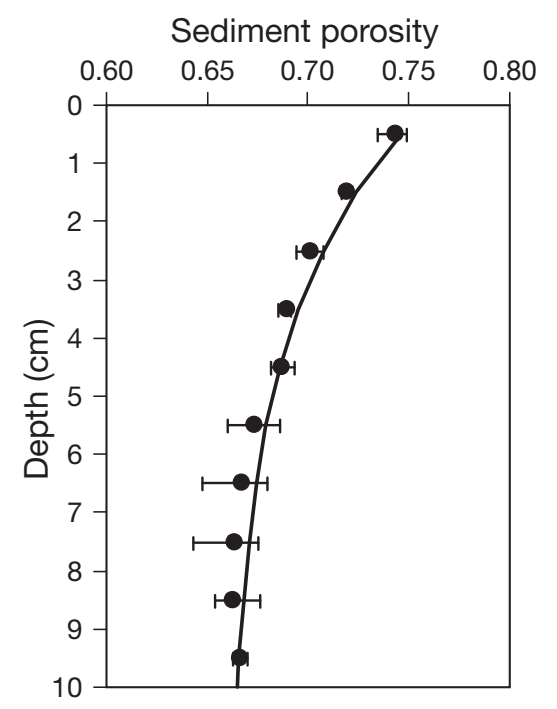

Fig. 3. Observed (solid dots) and modelled (solid line) depthdependent porosity profile. The line was computed according to: $\varphi(z)=\varphi_{\infty}+\left(\varphi_{0}-\varphi_{\infty}\right) \cdot \mathrm{e}^{(-\tau \cdot z)}$. Parameter values are listed in Table $5, z$ is in centimetres, and whiskers represent the minimum to maximum range of observed value ments are rich in terrigenous highly refractory OM. The C:N:P ratio for $\mathrm{OM}_{1}$ and $\mathrm{OM}_{2}$ were set according to literature values listed in Table 5. No distinction was made between feed and faeces, based on the assumption that the elemental composition of faeces reflects that of the ingested diet. The $\mathrm{OM}_{3}$ pool was considered separately in the model because the degradation rate constant for salmon farm deposits, $k_{3}$, is significantly higher than that of the $\mathrm{OM}_{1}$ pool. $k_{3}$ was set to $1 \mathrm{yr}^{-1}$, in accordance with the rates of salmon farm-derived OM decomposition reported by deBruyn \& Gobas (2004).

\section{RESULTS}

\section{Deposition model}

Fig. 4 shows the fluxes of farm-derived organic material, predicted by DEPOMOD. The model was forced using the values of fish biomass in the cages provided by the farmer for the period from March to August 2006 (Table 6). Mass balance calculations for the entire simulation revealed that $88 \%$ of $\mathrm{OM}_{3}$ remains in the computational domain $(400 \mathrm{~m} \times 300 \mathrm{~m})$ and $12 \%$ is exported. The deposition footprint is approximately elliptical and extends in a westerly direction from the salmon cages, which is consistent with the strong surface residual currents. The predicted deposition fluxes of $\mathrm{OM}_{3}$ at Stns $\mathrm{B}_{10}$ and $\mathrm{B}_{40}$ are also reported in Table 6 and show that this flux is remarkably higher in the summer months, as a result of the rapid increase in fish biomass. 


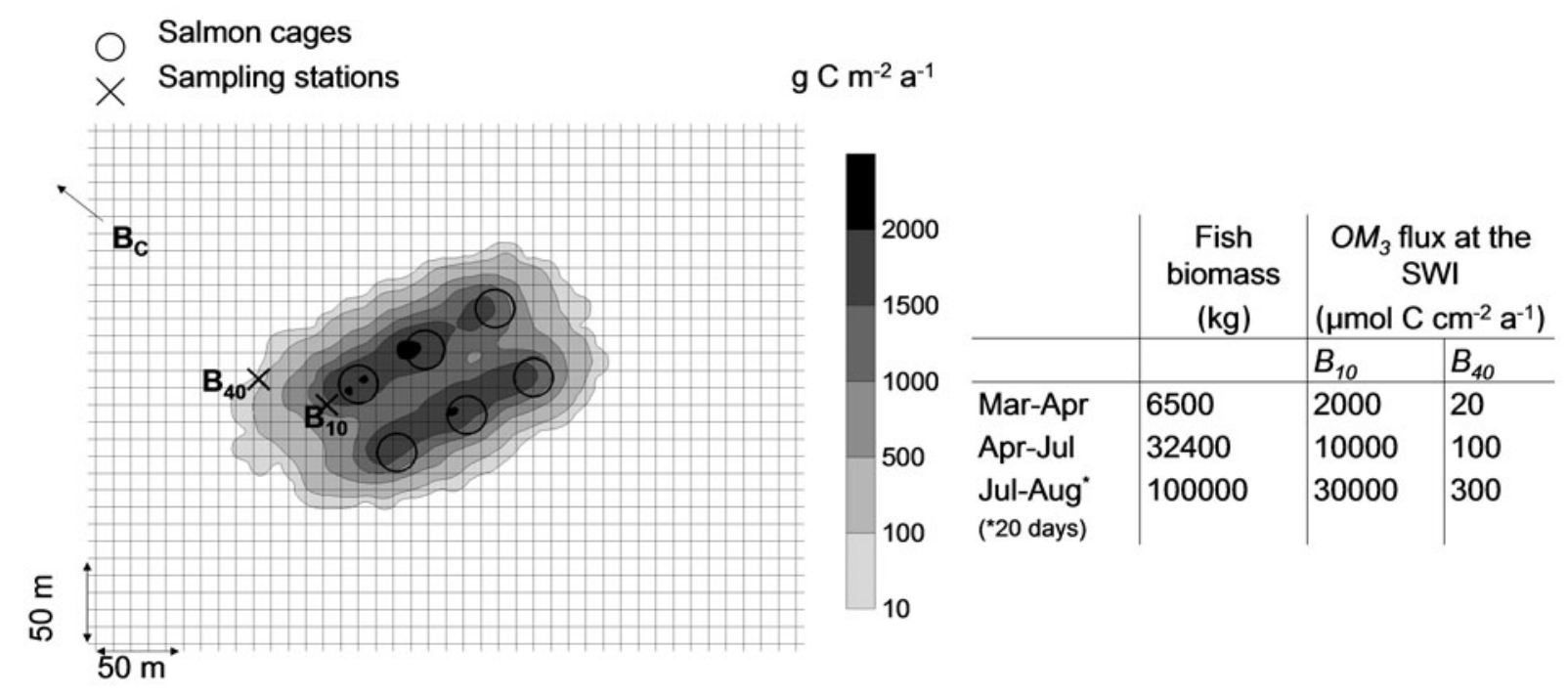

Fig. 4. Spatial distribution of carbon deposition flux predicted by DEPOMOD for the period from March to August 2006. OM: organic matter; SWI: sediment-water interface

\section{EDM calibration}

The model was calibrated under steady-state conditions by minimising the goal function, Eq. (3), against data collected at the pristine site, $\mathrm{B}_{\mathrm{C}}$. The optimal values for the solid deposition fluxes $\left[\mathrm{OM}_{\mathrm{T}}=\mathrm{OM}_{1}+\mathrm{OM}_{2}\right.$, $\mathrm{Mn}(\mathrm{IV})$ and $\mathrm{Fe}(\mathrm{III})]$ were found by comparing simulated and measured profiles of $\mathrm{OC}_{\mathrm{T}}\left(\mathrm{OC}_{1}+\mathrm{OC}_{2}\right), \mathrm{NH}_{4}{ }^{+}$, $\mathrm{SO}_{4}{ }^{2-}$, DIP (dissolved inorganic phosphorus), $\mathrm{Mn}^{2+}$ and $\mathrm{Fe}^{2+}$. The goal function was minimised over a range of $\mathrm{OM}_{\mathrm{T}}$ fluxes comprised between 50 and $400 \mu \mathrm{mol} \mathrm{C}$ $\mathrm{cm}^{-2} \mathrm{yr}^{-1}$, in agreement with values reported by Ansell (1974) and Cronin \& Tyler (1980) for Scottish sea lochs. As far as the fluxes of Fe(III) and Mn(IV) are concerned, no reference values were found for the study area; therefore, a broader range of values was explored, from 0.01 to $100 \mu \mathrm{mol} \mathrm{cm} \mathrm{cm}^{-2} \mathrm{yr}^{-1}$. Fluxes of $\mathrm{OM}_{\mathrm{T}}$, $\mathrm{Fe}(\mathrm{III})$ and $\mathrm{Mn}(\mathrm{IV})$ resulting from the model calibration are reported in Table 7 , while the observed and fitted model profiles are shown in Fig. 5. The 3 replicates show a significant variability, especially the nutrients. Simulated profiles of $\mathrm{NH}_{4}{ }^{+}, \mathrm{DIP}, \mathrm{SO}_{4}{ }^{2-}$ and $\mathrm{Fe}^{2+}$ con-

Table 6. Fish biomasses and $\mathrm{OM}_{3}$ fluxes at Stns $\mathrm{B}_{10}$ and $\mathrm{B}_{40}$. OM: organic matter; SWI: sediment-water interface

\begin{tabular}{|lccc|}
\hline & $\begin{array}{c}\text { Fish } \\
\text { biomass } \\
(\mathrm{kg})\end{array}$ & \multicolumn{2}{c|}{$\begin{array}{c}\mathrm{OM}_{3} \text { flux at the SWI } \\
\left(\mu \mathrm{mol} \mathrm{C} \mathrm{cm}^{-2} \mathrm{yr}^{-1}\right)\end{array}$} \\
\hline $\begin{array}{lccc}\mathrm{B} \\
\text { Mar-Apr }\end{array}$ & 6500 & 2000 & 20 \\
$\begin{array}{l}\text { Apr-Jul } \\
\text { Jul-Aug } \\
\text { a } 20 \mathrm{~d}\end{array}$ & 32400 & 10000 & 100 \\
\hline
\end{tabular}

centrations are in overall agreement with field data, and, generally, within the range of observations. OC concentrations decrease only slightly with depth, corroborating the hypothesis that a substantial part of the $\mathrm{OM}$ is refractory. As far as the OC is concerned, the model slightly underestimated the concentration in the uppermost sediment layer. The model also largely underestimates $\mathrm{Mn}^{2+}$ in the upper layers of the sediment.

Table 7. Upper boundary conditions for the early diagenesis model. Values for solutes were constrained from observations. Solid flux values were estimated by fitting the model to the field data collected at Stn $\mathrm{B}_{\mathrm{C}}$. TS: total sulphides; DIP: dissolved inorganic phosphorus; OM: organic matter

\begin{tabular}{|c|c|c|}
\hline Species & $\begin{array}{c}\text { Upper } \\
\text { boundary } \\
\text { condition }\end{array}$ & Data source \\
\hline \multicolumn{3}{|c|}{ Solute concentrations $\left(\mu \mathrm{mol} \mathrm{l}^{-1}\right)$} \\
\hline $\mathrm{O}_{2}$ & 189 & Rabouille pers. comm. \\
\hline $\mathrm{NO}_{3}^{-}$ & 4.7 & Present study \\
\hline $\mathrm{NH}_{4}^{+}$ & 1.8 & Present study \\
\hline $\mathrm{SO}_{4}^{2-}$ & $28 \times 10^{3}$ & Present study \\
\hline $\mathrm{Mn}^{2+}$ & 3.34 & Present study \\
\hline $\mathrm{Fe}^{2+}$ & 1.0 & Present study \\
\hline $\mathrm{TS}\left(\mathrm{H}_{2} \mathrm{~S}+\mathrm{HS}\right.$ & 0 & Rabouille pers. comm. \\
\hline DIP & 0.4 & Present study \\
\hline $\mathrm{CH}_{4}$ & 0 & Present study \\
\hline \multicolumn{3}{|c|}{ Solid fluxes } \\
\hline $\mathrm{OM}_{1}+\mathrm{OM}_{2}$ & $120\left(\mu \mathrm{mol} \mathrm{cm}{ }^{-2} \mathrm{yr}^{-1}\right)$ & Model calibration \\
\hline $\mathrm{OM}_{1} / \mathrm{OM}_{2}$ & $2(-)$ & $\begin{array}{l}\text { Derived from Loh et al. } \\
\text { (2002) }\end{array}$ \\
\hline $\mathrm{MnO}_{2}$ & $1.0\left(\mu \mathrm{mol} \mathrm{cm}{ }^{-2} \mathrm{yr}^{-1}\right)$ & Model calibration \\
\hline $\mathrm{Fe}(\mathrm{OH})_{3}$ & $7.5\left(\mu \mathrm{mol} \mathrm{cm}{ }^{-2} \mathrm{yr}^{-1}\right)$ & Model calibration \\
\hline FeS & $0\left(\mu \mathrm{mol} \mathrm{cm}{ }^{-2} \mathrm{yr}^{-1}\right)$ & - \\
\hline
\end{tabular}



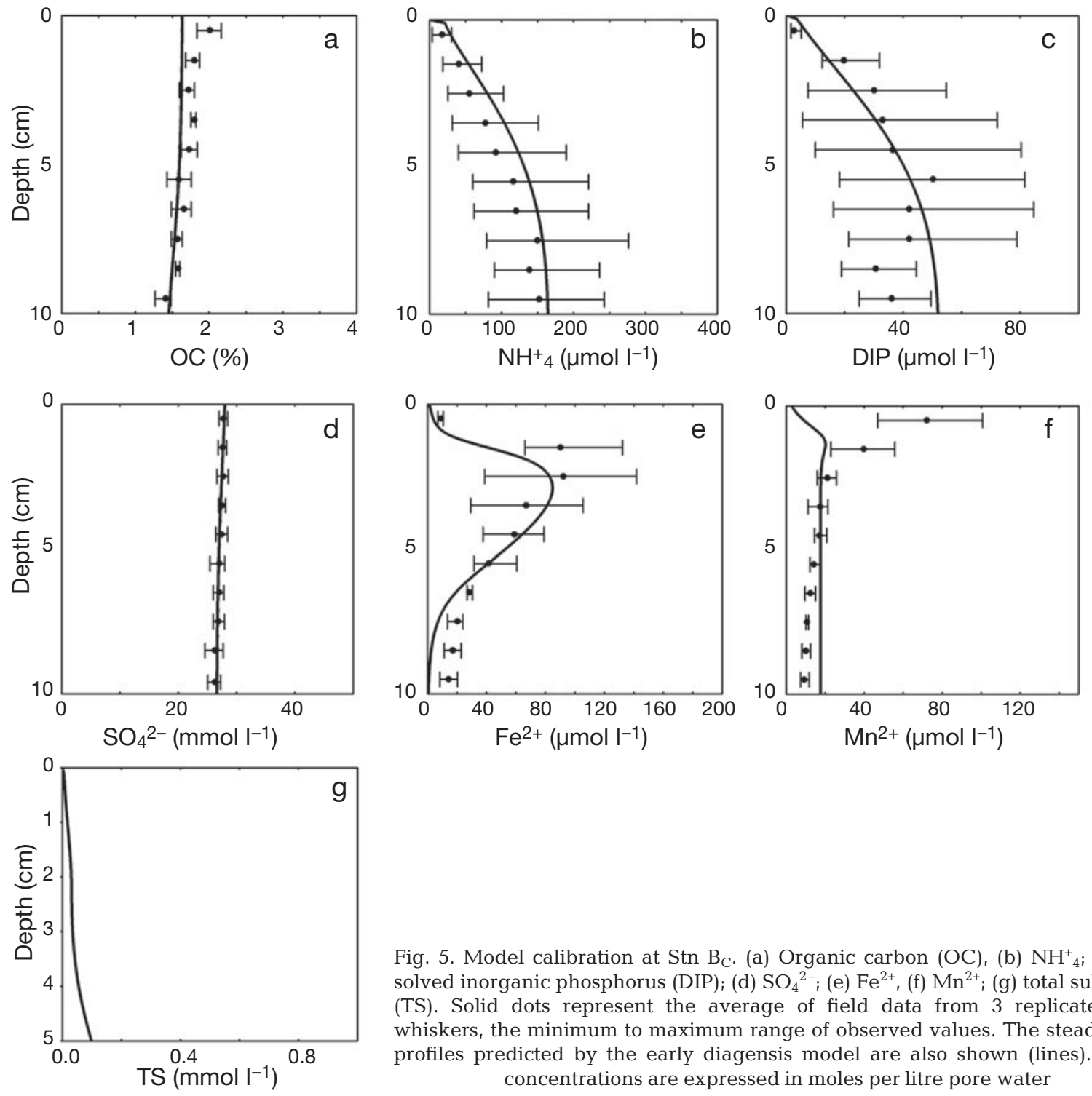

Fig. 5. Model calibration at Stn $\mathrm{B}_{\mathrm{C}}$. (a) Organic carbon (OC), (b) $\mathrm{NH}_{4}^{+}$; (c) dissolved inorganic phosphorus (DIP); (d) $\mathrm{SO}_{4}{ }^{2-} ;$ (e) $\mathrm{Fe}^{2+}$, (f) $\mathrm{Mn}^{2+} ;$ (g) total sulphides (TS). Solid dots represent the average of field data from 3 replicates, and whiskers, the minimum to maximum range of observed values. The steady-state profiles predicted by the early diagensis model are also shown (lines). Solute concentrations are expressed in moles per litre pore water

Depth-integrated rates of carbon mineralisation in the upper $40 \mathrm{~cm}$ of sediment are reported in Table 8; $40 \%$ of the carbon mineralisation occurs aerobically, the remaining being attributed to mainly sulphate reduction. The depth-integrated oxic mineralisation rate reported here falls within the range of 15 to $77 \mu \mathrm{mol} \mathrm{C}$ $\mathrm{cm}^{-2} \mathrm{yr}^{-1}$, derived by Canfield et al. (1993) from incubation experiments in coastal marine sediments. The rate of dissimilatory iron reduction is also similar to that found by Canavan et al. (2006).

\section{EDM transient simulations}

At $\mathrm{Stn} \mathrm{B}_{40}$, the average $\mathrm{OM}_{3}$ flux predicted by DEPOMOD (Fig. 4) is $0.1 \mathrm{mmol} \mathrm{C} \mathrm{cm}{ }^{-2} \mathrm{yr}^{-1}$, very close to the $0.12 \mathrm{mmol} \mathrm{C} \mathrm{cm}^{-2} \mathrm{yr}^{-1}$ of the natural $\mathrm{OM}_{\mathrm{T}}$ flux reported in Table 7 for $\mathrm{Stn} \mathrm{B}_{\mathrm{C}}$. Therefore, it is not surprising that the measured $\mathrm{OC}, \mathrm{NH}_{4}{ }^{+}$, DIP and $\mathrm{SO}_{4}{ }^{2-}$ concentration profiles are similar to those of the control station $B_{C}$ (Fig. 6). Stn $B_{40}$ is thus weakly impacted by the fish farm organic activities, and the variations in concentrations could thus also be due to the natural variability in sediment composition in the area. The transient evolution of concentration profiles triggered by fish farming are consequently only modelled at $\mathrm{Stn} \mathrm{B}_{10}$, where the average $\mathrm{OM}_{3}$ flux is much larger $\left(10 \mathrm{mmol} \mathrm{C} \mathrm{cm} \mathrm{Cr}^{-1}\right)$ and significant perturbations of the pristine biogeochemical conditions can, therefore, be expected.

To set-up Nominal Run 1, the following steps were carried out:

(1) The $\mathrm{OM}_{3}$ flux predicted by DEPOMOD at Stn $\mathrm{B}_{10}$ was imposed as an additional source of labile OM for the EDM in addition to the deposition flux of $\mathrm{OM}_{1}$ and $\mathrm{OM}_{2}$; 
Table 8. Simulated depth-integrated rates of organic carbon (OC) mineralisation through the various metabolic pathways at Stn $B_{C}$. See 'Results-EDM calibration' for the further details

\begin{tabular}{|lc|}
\hline Pathway & $\begin{array}{c}\text { OC mineralisation rate } \\
\left(\mu \mathrm{mol} \mathrm{C} \mathrm{cm}^{-2} \mathrm{yr}^{-1}\right)\end{array}$ \\
\hline Oxic respiration & 32.1 \\
Denitrification & 1.2 \\
Mn(IV) reduction & 0.02 \\
Fe(III) reduction & 2.7 \\
Sulphate reduction & 44.0 \\
Methanogenesis & 0 \\
Total & 80.02 \\
\hline
\end{tabular}

(2) The initial conditions of the system were set according to the steady-state results obtained at Stn $\mathrm{B}_{\mathrm{C}}$ (Fig. 5);

(3) The model was run under transient conditions for $3 \mathrm{yr}$, and a snapshot was extracted at $0.5 \mathrm{yr}$, corresponding to a time for which field data were available.

For the transient simulation, the boundary conditions were constrained as follows. Based on the DEPOMOD results, the $\mathrm{OM}_{3}$ flux was assumed to increase in 3 steps, according to Fig. $7 \mathrm{~b}$, and to remain constant thereafter. A time variable bioturbation coefficient, linearly decreasing to zero within the 5 mo period was also imposed (Fig. 7), in agreement with the observations that sediments are azoic at Stn $B_{10}$. During the transient period, the burial rate was increased proportionally to the $\mathrm{OM}_{3}$ fluxes. The effects of very high sulphate reduction rates on sulphate concentration within the topmost few millimetres of the sediment were accounted for by imposing a decreasing sulphate concentration at the upper boundary.

The transient results from the nominal run generally capture the main trends of the field data collected after $0.5 \mathrm{yr}$, with large increases in $\mathrm{OC}, \mathrm{NH}_{4}{ }^{+}$and DIP concentrations, and a marked drop in $\mathrm{SO}_{4}{ }^{2-}$ concentrations (Fig. 8a to d). OC concentrations in the top $2 \mathrm{~cm}$ of the sediment reach values 8 times higher than at $\mathrm{B}_{\mathrm{C}}$, whereas the concentrations deeper in the sediment remain of comparable magnitude. Due to the mineralisation of large amounts of fish farm-derived labile OM, $\mathrm{NH}_{4}^{+}$and DIP concentrations at Stn $\mathrm{B}_{10}$ were approximately 10 times higher than those at Stn $\mathrm{B}_{\mathrm{C}}$ (Fig. 5). Sub-surface maxima in nutrient concentrations were localised at around $5 \mathrm{~cm}$ depth, concomitant with a zone of sub-millimolar dissolved sulphate
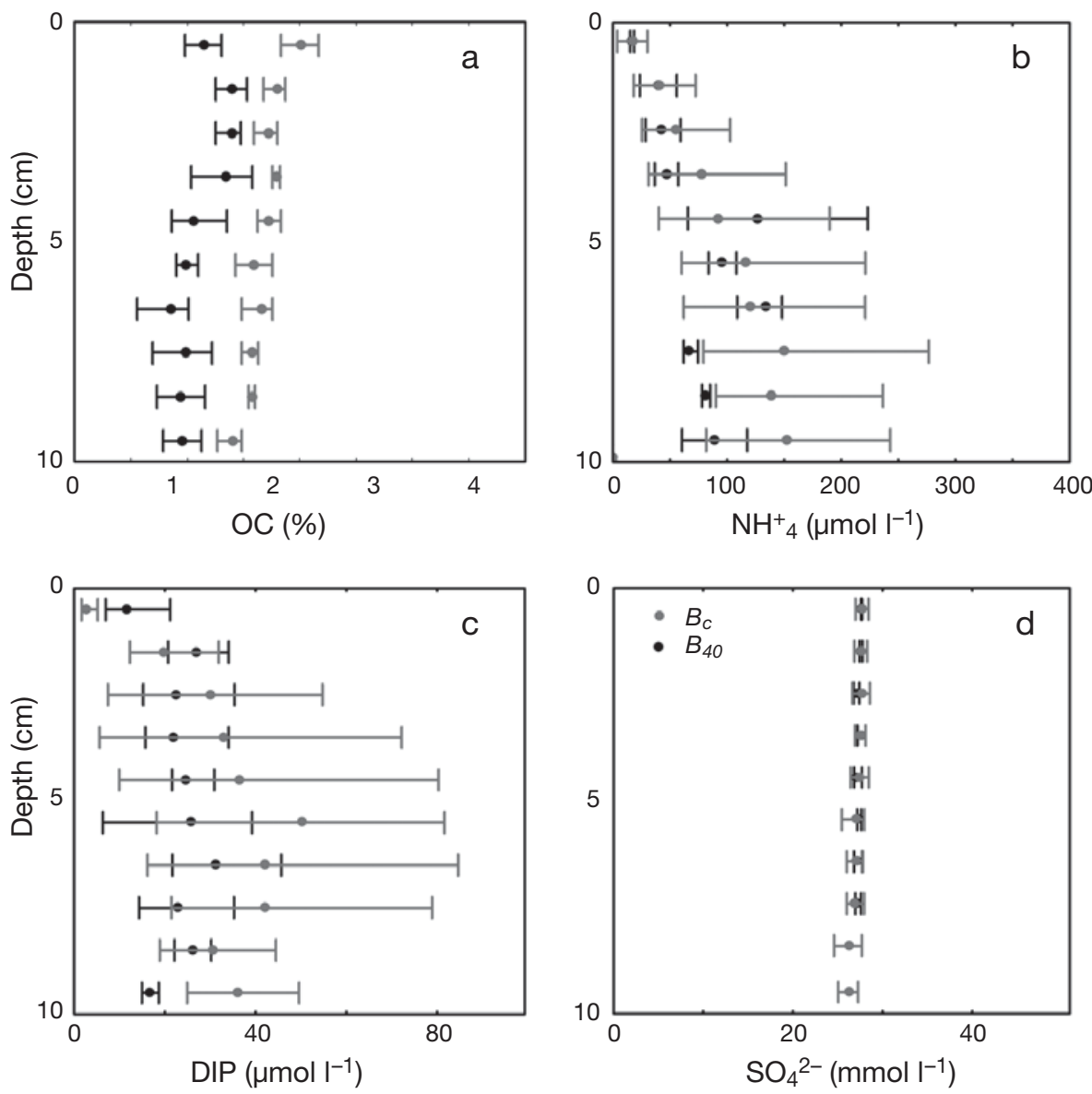

Fig. 6. Measured (a) organic carbon (OC), (b) $\mathrm{NH}_{4}^{+}$, (c) dissolved inorganic phosphorus (DIP) and (d) $\mathrm{SO}_{4}{ }^{2-}$ concentration profiles, at Stns $\mathrm{B}_{\mathrm{C}}$ (grey) and $\mathrm{B}_{40}$ (black). Points represent average values, and whiskers, the minimum to maximum range of observed values. Solute concentrations are expressed in moles per litre pore water 


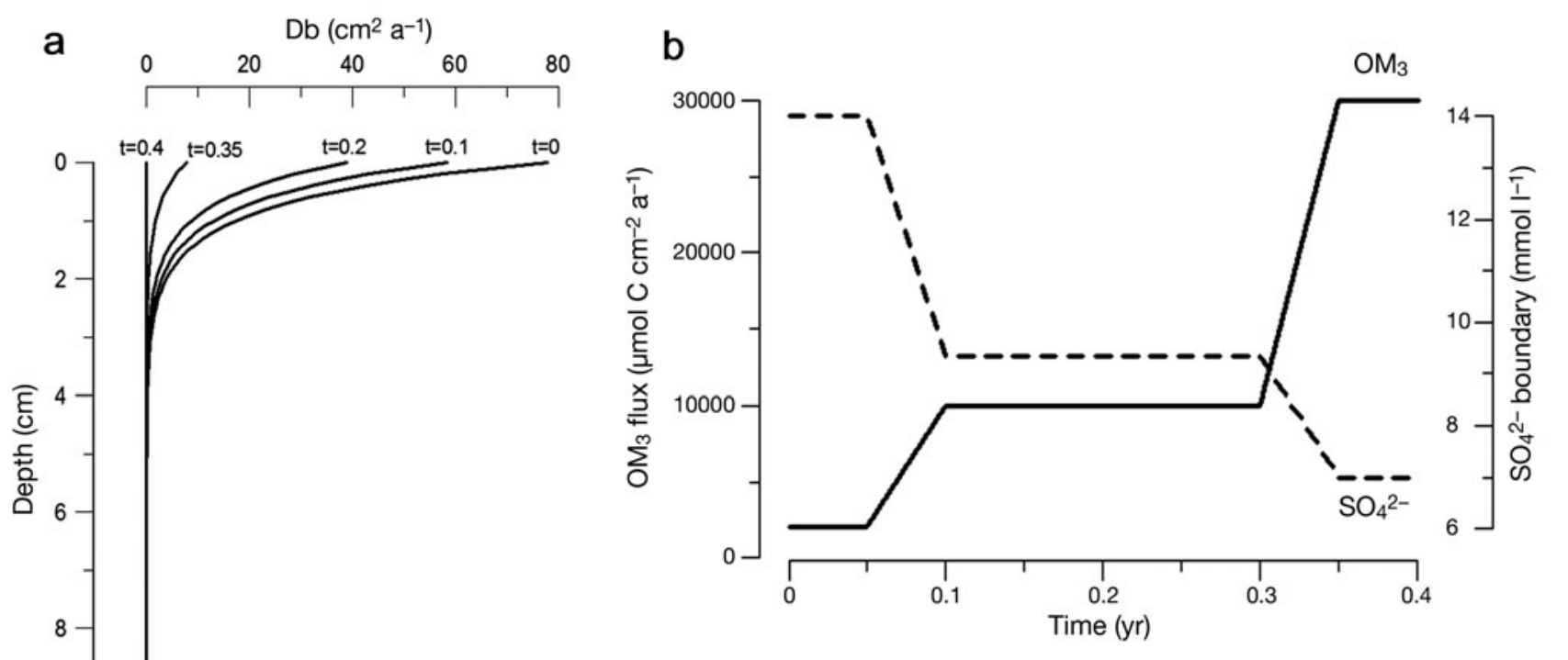

Fig. 7. Transient dynamics at Stn $\mathrm{B}_{10}$. (a) Time evolution of the bioturbation coefficient and (b) the $\mathrm{OM}_{3}$ flux and the $\mathrm{SO}_{4}{ }^{2-}$ concentration at the upper boundary

concentrations. The depths of nutrient maxima predicted by the model were in good agreement with the field data, even though the DIP profile and $\mathrm{NH}_{4}{ }^{+}$concentrations below $6 \mathrm{~cm}$ were slightly underestimated. Measured dissolved $\mathrm{Fe}^{2+}$ and $\mathrm{Mn}^{2+}$ concentrations were always very low, without any visible distinction between different replicates. The absence of dissolved $\mathrm{Fe}^{2+}$ was also predicted by the model, while model-predicted $\mathrm{Mn}^{2+}$ were slightly overestimated compared to field data, most likely because $\mathrm{MnCO}_{3}$ precipitation was not included in the reaction network (see Appendix 1).

In Sensitivity Run 2, a variation of the $\mathrm{OM}_{3}$ flux of $\pm 50 \%$ was applied, according to the range of uncertainty of the DEPOMOD predictions (Cromey et al. 2002a). The grey lines in Fig. 8 show that the boundary condition variations induced remarkable changes in concentration profiles, especially for $\mathrm{NH}_{4}{ }^{+}$and DIP. For these species, the model variability was higher than the variability in field data, as indicated by the black whiskers. Fig. 8d shows that $\mathrm{SO}_{4}{ }^{2-}$ was also affected by changes in $\mathrm{OM}_{3}$ fluxes and was totally consumed in the $+50 \% \mathrm{OM}_{3}$ run at depths between 2 and $5 \mathrm{~cm}$. In this case, the most important OM mineralisation pathway at 0.5 yr was no longer sulphate reduction, but methanogenesis.

The model was used for prognostic purposes, and the biogeochemical dynamics investigated over a much longer period of $3 \mathrm{yr}$ until a new steady-state, consistent with an $\mathrm{OM}_{3}$ flux of $30 \mathrm{mmol} \mathrm{C} \mathrm{cm} \mathrm{Cr}^{-1}$, was reached. In this simulation, the $\mathrm{OM}_{3}$ boundary flux was first set according to Fig. $7 b$, and then assumed to be constant in time, since no data on fish biomass in the cages were available after $0.4 \mathrm{yr}$. Table 9 shows the evolution in depth-integrated pathways of OM oxidation. After $2 \mathrm{yr}$, the total depthintegrated rate of $\mathrm{OM}$ degradation reached $30 \mathrm{mmol}$ $\mathrm{C} \mathrm{cm}^{-2} \mathrm{yr}^{-1}$, corresponding to the imposed $\mathrm{OM}_{1}+$ $\mathrm{OM}_{3}$ fluxes at the SWI. At this stage, steady-state conditions were established with respect to the maximum deposition flux of $\mathrm{OM}_{3}$. First, oxic degradation increased sharply, concomitant with the enhanced deposition of $\mathrm{OM}_{3}$, then decreased slightly after 6 mo, due to the intense competition of SRR for oxygen by secondary redox reactions. Sulphate reduction rates showed also a rapid initial increase, which levels off after 6 mo. In relative terms, these 2 pathways contributed roughly equally to the total mineralisation rate during the increasing stages of $\mathrm{OM}_{3}$ deposition. However, after $6 \mathrm{mo}$, methanogenesis became rapidly the most important pathway of OM decomposition and, after $2 \mathrm{yr}$, contributed $89 \%$ of the total mineralisation, sulphate reduction reaching barely $8 \%$ and oxic respiration $3 \%$. The TS (total sulphides; $\mathrm{H}_{2} \mathrm{~S}+$ $\mathrm{HS}^{-}$) flux through the SWI increased steadily and reached values as high as $1.5 \mathrm{mmol} \mathrm{S} \mathrm{cm}^{-2} \mathrm{yr}^{-1}$. The progressive increase in the OM load and mineralisation also led to enhanced fluxes of DIP and ammonium through the SWI. This is in agreement with observations by Hargrave et al. (1993). The oxygen penetration depth (not shown) and the oxygen flux through the SWI did not change during the transient simulation period. The oxygen flux, on average, $1166 \mu \mathrm{mol} \mathrm{O} \mathrm{O}_{2} \mathrm{~cm}^{-2} \mathrm{yr}^{-1}$, fell within the range recently measured by Dedieu et al. (2007) for a French lagoon (730 to $2190 \mu \mathrm{mol} \mathrm{O} \mathrm{cm}^{-2} \mathrm{yr}^{-1}$ ). 

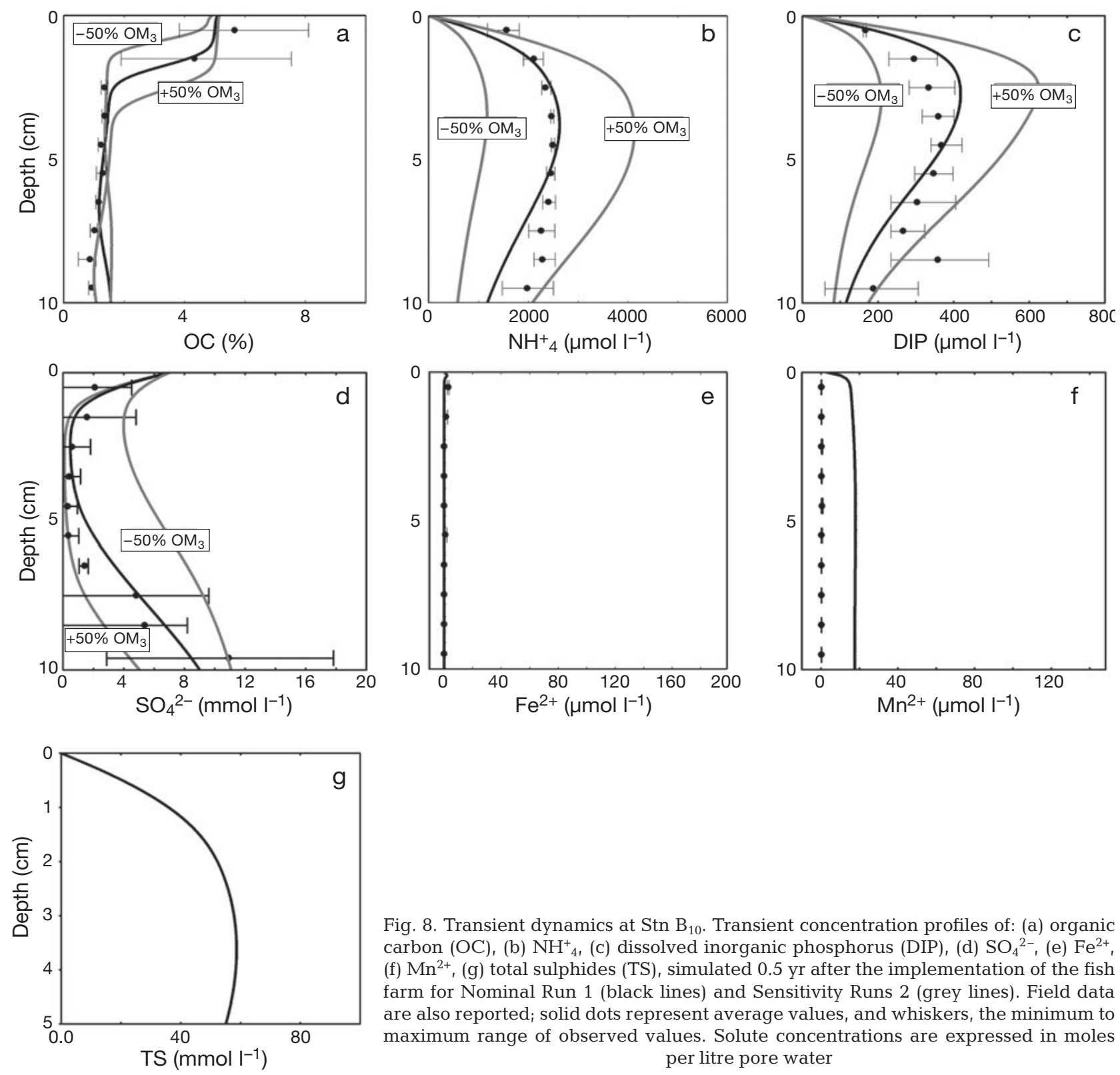

Fig. 8. Transient dynamics at $\mathrm{Stn} \mathrm{B}_{10}$. Transient concentration profiles of: (a) organic carbon (OC), (b) $\mathrm{NH}_{4}^{+}$, (c) dissolved inorganic phosphorus (DIP), (d) $\mathrm{SO}_{4}{ }^{2-}$, (e) $\mathrm{Fe}^{2+}$, (f) $\mathrm{Mn}^{2+},(\mathrm{g})$ total sulphides (TS), simulated $0.5 \mathrm{yr}$ after the implementation of the fish farm for Nominal Run 1 (black lines) and Sensitivity Runs 2 (grey lines). Field data are also reported; solid dots represent average values, and whiskers, the minimum to maximum range of observed values. Solute concentrations are expressed in moles per litre pore water

Table 9. Time evolution (in yr) of organic matter (OM) deposition flux, total depth-integrated rates of organic carbon oxidation, relative contribution of aerobic respiration, sulphate reduction and methanogenesis at Stn $\mathrm{B}_{10}$. The fluxes of TS (total sulphides, $\mathrm{H}_{2} \mathrm{~S}+\mathrm{HS}^{-}$), nutrients (dissolved inorganic phosphorus [DIP], $\mathrm{NH}_{4}{ }^{+}$) and oxygen are also reported. The fluxes were computed by means of a third-order-accurate approximation of the concentration gradient (Boudreau 1997)

\begin{tabular}{|c|c|c|c|c|c|c|}
\hline & 0 & 0.25 & 0.5 & 1 & 2 & 3 \\
\hline OM flux $\left(\mathrm{OM}_{1}+\mathrm{OM}_{3}\right)\left[\mathrm{\mu mol} \mathrm{C} \mathrm{cm}{ }^{-2} \mathrm{yr}^{-1}\right]$ & 80 & 10080 & 30080 & 30080 & 30080 & 30080 \\
\hline Integrated rate $\left[\mu \mathrm{mol} \mathrm{C} \mathrm{cm}^{-2} \mathrm{yr}^{-1}\right]$ & 80 & 2559 & 8223 & 17698 & 30055 & 30070 \\
\hline Aerobic respiration [\%] & 40 & 61 & 33 & 11 & 4 & 3 \\
\hline Sulphate reduction [\%] & 55 & 39 & 29 & 13 & 8 & 8 \\
\hline Methanogenesis [\%] & 0 & 0 & 38 & 76 & 88 & 89 \\
\hline TS flux $\left[\mu \mathrm{mol} \mathrm{cm} \mathrm{cm}^{-2} \mathrm{yr}^{-1}\right]$ & 19 & 333 & 1002 & 1131 & 1307 & 1464 \\
\hline DIP $\left[\mu \mathrm{mol} \mathrm{cm} \mathrm{cr}^{-2} \mathrm{yr}^{-1}\right]$ & 4 & 19 & 45 & 96 & 184 & 271 \\
\hline $\mathrm{NH}_{4}^{+}\left[\mu \mathrm{mol} \mathrm{cm}^{-2} \mathrm{yr}^{-1}\right]$ & 79 & 253 & 478 & 921 & 1690 & 2739 \\
\hline $\mathrm{O}_{2}\left[\mu \mathrm{mol} \mathrm{cm} \mathrm{cm}^{-2} \mathrm{yr}^{-1}\right]$ & -1163 & -1153 & -1171 & -1176 & -1177 & -1178 \\
\hline
\end{tabular}




\section{DISCUSSION}

\section{Calibration of the EDM}

The calibration procedure provided estimates of the deposition fluxes of $\mathrm{OM}, \mathrm{Fe}(\mathrm{OH})_{3}$ and $\mathrm{MnO}_{2}$ at the SWI of Stn $\mathrm{B}_{\mathrm{C}}$ for which field data were not available. A similar approach was previously adopted by Wang \& van Cappellen (1996) and Canavan et al. (2006). Here, however, the calibration was performed using a goal function, instead of carrying out the adjustment of these forcings by visual inspection only. The systematic exploration of the entire space of possible boundary condition values represents a much more robust and reproducible way to calibrate a model.

The main objective of model calibration was to provide well constrained initial concentration profiles for the transient simulation corresponding to pristine conditions. We chose to compare the model results with the mean observed values, thus ignoring the variability between the 3 replicates. Therefore, model results are intended to provide an overall picture of the steadystate diagenesic processes and not to explain the observed discrepancies at each site. The dissolved ferrous iron, which was produced mainly by dissimilatory $\mathrm{Fe}^{3+}$ reduction (Reaction 4 in Appendix 1) was consumed by re-oxidation and FeS precipitation (Reactions 8, 9 and 12 in Appendix 1). Within the depth range of 6 to $10 \mathrm{~cm}$, FeS precipitation dominated (results not shown) and might have been overestimated. The underestimated superficial concentration of $\mathrm{Mn}^{2+}$ predicted by the model could be due to rates of reoxidation through the overestimated aerobic pathway (Process 7 in Appendix 1), which outcompeted production, by $\mathrm{Mn}(\mathrm{IV})$ reduction, $\mathrm{Fe}^{2+}$ and $\mathrm{TS}$ reoxidation (Processes 3, 9 and 11 in Appendix 1). Even though the lack of fit in some portions of the profile for the trace metals is a potential drawback of setting the kinetic constants on the basis of literature values, their further calibration would be difficult without additional, reliable field information on the in situ kinetic rates, as well as on the concentrations of solid Mn(IV) and Fe(III) oxides.

\section{Transient simulations}

Soetaert et al. (1996) studied the diagenetic response of sediments subject to seasonally varying carbon deposition fluxes by means of a dynamic model. The model was run for 3 yr using as input the same annual time series of data, in order to achieve a periodic regime at the interannual time scale. A similar approach was recently used by Dale et al. (2008b) in anoxic sediments in Aarhus Bay, Denmark. In the study by Soetaert et al. (1996), the model parameters were calibrated to produce profiles that best fitted the experimental data collected at the same location in 2 subsequent years. Here, we propose a different strategy, calibrating first the model at one location under steady-state conditions and, then, using another independent dataset, testing the dynamic response of the system triggered by perturbation. This procedure can be regarded as an efficient way to assess model robustness, since it indicates that the model provides reasonable results in response to changes in the boundary conditions. This is a desirable property for a dynamic model, in particular if it is used to simulate transient scenarios (Canavan et al. 2006, Dale et al. 2008b).

The dynamic response of the EDM, importing from the steady-state conditions prevailing at $\operatorname{Stn} \mathrm{B}_{\mathrm{C}}$, was investigated by adding the $\mathrm{OM}_{3}$ deposition fluxes quantified by DEPOMOD to the natural contribution. The reliability of the transient results depends on the reliability of the model-predicted OC rain rates. The results from DEPOMOD were validated by means of sediment trap data, which were collected in similar sea loch environments (Cromey et al. 2002a); and the model is now used for regulatory purposes throughout Scotland. In addition, the results presented here (Stn $\mathrm{B}_{10}$; Fig. 8) indicate that the coupled DEPOMOD and EDM models led to a reasonable description of the dynamics of early diagenesis under transient conditions, providing supplementary evidence that the estimate of the deposition flux is robust. The sensitivity test of EDM results to the changes in $\mathrm{OM}_{3}$ deposition fluxes, furthermore, revealed that the diagenetic profiles were highly sensitive to this flux.

The field data collected at Stns $\mathrm{B}_{\mathrm{C}}$ and $\mathrm{B}_{40}$ indicated similar concentrations of $\mathrm{OC}, \mathrm{SO}_{4}{ }^{2-}$, DIP and $\mathrm{NH}_{4}{ }^{+}$ (Fig. 6). Modification in sediment geochemistry induced by enhanced OC deposition was much more obvious at $\mathrm{Stn} \mathrm{B}_{10}$, a result in agreement with previous studies (Hargrave et al. 1993, Wildish et al. 1993, Pitta et al. 1998). The transient simulation of OM deposition and diagenetic response captured the dominant variations of OC, DIP, $\mathrm{NH}_{4}{ }^{+}, \mathrm{SO}_{4}{ }^{2-}$ and dissolved metal concentrations measured in the field. The coupled model also provided valuable information about the magnitude of fluxes of dissolved nutrients and TSs, which are required data for the implementation of sustainable aquaculture facilities. As regards model limitations, in cases of water bodies characterised by relatively high residence times, the transience of the SWI fluxes of oxygen and dissolved nutrients could, in principle, be simulated more accurately based on time-varying boundary conditions. This requires time series of data, from in situ on-line probes or from forecasts obtained by means of pelagic biogeochemical models. The uncertainty associated with this data may, in turn, de- 
crease the robustness of the predictions of the diagenetic model. For this reason, the trade-off between costs and benefits associated with the introduction of time-variable boundary conditions should be carefully evaluated for each species considered.

\section{Aquaculture-related model application}

With respect to the aquaculture industry, the integrated model is useful: (1) to help support environmental impact assessment (EIA) and site selection studies, and (2) for the optimisation of farming densities and husbandry practices.

Wildish et al. (2001) investigated the cost-effectiveness of methods based, on the one hand, on macrofaunal community structure, and, on the other hand, on redox potential (Eh) and TS measurements. They concluded that the latter approach was superior to monitor the impact of fish farming. Even though macrofaunal measurements are currently adopted in most monitoring programs, these authors suggested that rapidity, ease and transferability were 3 major advantages of the geochemical approach. From a prognostic perspective, the models presented here complement judiciously the sedimentary monitoring programmes, especially in the context of EIA and aquaculture site selection. For instance, Hargrave et al. (1997) ranked the sensitivity of 20 different indicators of organic enrichment under salmon net-pens in the Bay of Fundy (Canada) and proposed that TS flux, total $\mathrm{CO}_{2}$ release and total $\mathrm{O}_{2}$ uptake were the most sensitive indicators. In the future, the coupled model developed in the present study could help refine the choice of the most cost-effective indicators of organic enrichment.

Dissolved oxygen and TS were 2 cost-effective variables included in the model. The TS concentration at Site $\mathrm{B}_{10}$ increased dramatically from sub-millimole levels to concentrations $>5 \mathrm{mmol} \mathrm{l}^{-1}$ within a few months (Figs. $5 g$ \& 8g), a level potentially toxic to benthic infauna. The predicted concentrations are, however, lower than the values of $>100 \mathrm{mmol} \mathrm{l}^{-1}$ reported by Hargrave et al. (1993) at a salmon farm in the Bay of Fundy (Canada). The levels reported here are of the same order of magnitude as those measured in September 2006 by microelectrode profiling at a Loch Creran recovery site where salmon were reared until
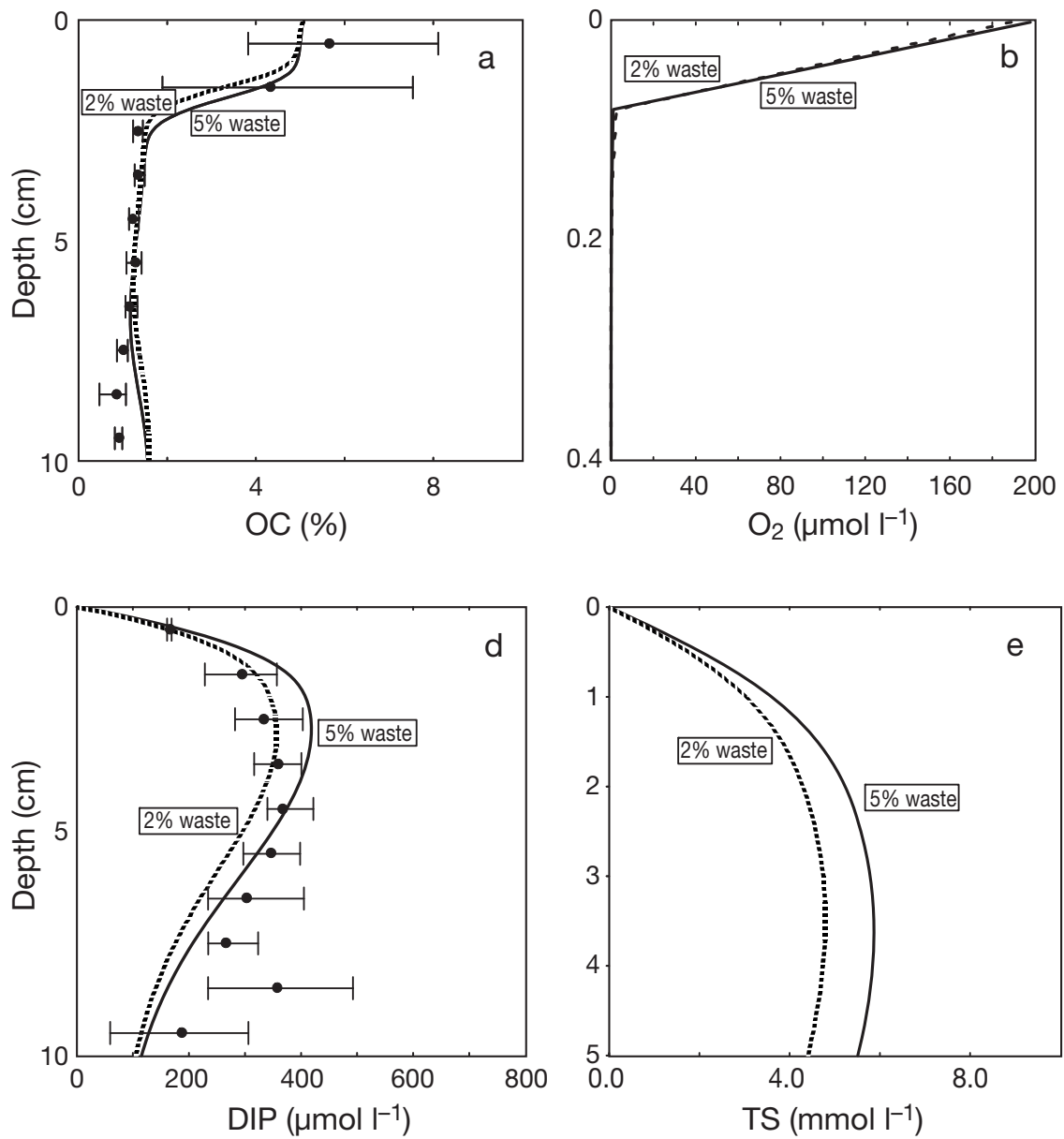

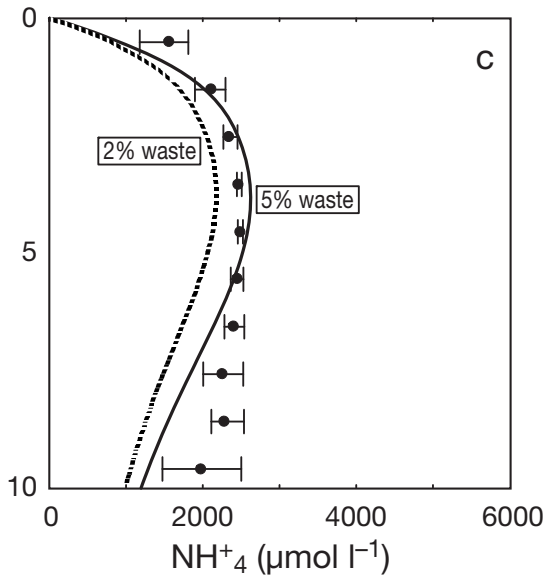

Fig. 9. Vertical profiles of: (a) organic carbon (OC), (b) $\mathrm{O}_{2}$, (c) $\mathrm{NH}_{4}{ }^{+}$, (d) dissolved inorganic phosphorus (DIP) and (e) total sulphides (TS) at Stn $\mathrm{B}_{10}$ for $5 \%$ (solid line) and $2 \%$ (dashed line) fish food wastage 
December 2005 (Rabouille pers. comm.). The low oxygen penetration depth predicted by the model, approximately $1 \mathrm{~mm}$, is also in agreement with oxygen microprofiles reported elsewhere (see www.cobo.org.uk). In the future, the set of variables commonly measured in the field of aquaculture, e.g. OC and nutrients, could thus be extended to other geochemically based measurements, such as dissolved oxygen and sulphide microprofiles.

The coupled model can also support the estimation of husbandry practices. In this context, DEPOMOD was run again by assuming a lower percentage of fish food wasted, $2 \%$ instead of $5 \%$, see data in Table 3 ; this lowered the $\mathrm{OM}_{3}$ deposition fluxes at Stn $B_{10}$, from an average value of 10 to $8.5 \mathrm{mmol} \mathrm{C}$ $\mathrm{cm}^{-2} \mathrm{yr}^{-1}$. The EDM transient simulation was then repeated by imposing the lowered $\mathrm{OM}_{3}$ flux at the upper boundary. Fig. 9 compares the resulting vertical profiles to those obtained under the assumption of a $5 \%$ of food wastage. The results reveal that dissolved nutrients and TS are the most sensitive variables, while $\mathrm{OC}$ and $\mathrm{O}_{2}$ profiles remain essentially unaltered. The integrated model can thus help identify which geochemical variables are the most suitable to assess the impact of fish farming on the environment. It also provides a qualitative means to evaluate the effects of improved husbandry practices on water quality.

\section{CONCLUSIONS}

A model integrating deposition and early diagenesis of carbon has been developed and used in the context of aquaculture site selection, EIA and monitoring. On the basis of the model results, we have shown that the model provides a qualitative, robust means to evaluate the alteration of environmental conditions (nutrients, toxic compounds) as a result of fish farming activities. We advocate its use in combination with classical geochemical measures (e.g. $\left.\mathrm{NH}_{4}{ }^{+}, \mathrm{DIP}\right)$ as a cost-effective means of EIA, but also together with alternative indicators, such as pore water oxygen and sulphide concentrations.

Acknowledgements. The authors gratefully acknowledge the assistance of Ms. S. McKinlay with core slicing, Mrs. H. Orr with CHN analysis, Ms. C. Haidon with metals analysis, Mr. T. Brand for phosphate analysis and Mr. M. Harvey with sulphate analysis. This work has been financially supported by EU Project No. 006540 (ECASA), by the Netherlands Organization for Scientific Research (NWO) (VIDI Award 864.05.007 to P.R.) and by the government of the Brussels-Capital region ('Brains Back to Brussels' award to P.R.). This work benefited from the useful comments by 3 anonymous referees.

\section{LITERATURE CITED}

Aguilera DR, Jourabchi P, Spiteri C, Regnier P (2005) A knowledge-based reactive transport approach for the simulation of biogeochemical dynamics in Earth systems. Geochem Geophys Geosyst 6:Q07012

Ansell AD (1974) Sedimentation of organic detritus in Lochs Etive and Creran, Argyll, Scotland. Mar Biol 27:263-273

> Aspila KI, Agemain H, Chau A (1976) A semi-automated method for the determination of inorganic, organic and total phosphorus in sediments. Analyst (Lond) 101:187-197

Barnett PRO, Watson J, Connelly D (1984) A multiple corer for taking virtually undisturbed samples from shelf, bathyal and abyssal sediments. Oceanol Acta 7:399-408

Berg P, Rysgaard S, Thamdrup B (2003) Dynamic modeling of early diagenesis and nutrient cycling: a case study in an arctic marine sediment. Am J Sci 303:905-955

Berner RA (1980) Early diagenesis: a theoretical approach. Princeton University Press, Princeton, NJ

Black KD (2001) Environmental impacts of aquaculture. Sheffield Academic Press, Sheffield

Boudreau BP (1997) Diagenetic models and their implementation: modeling transport and reactions in aquatic sediments. Springer, New York

Canavan RW, Slomp CP, Jourabchi P, van Cappellen P, Laverman AM, van den Berg GA (2006) Organic matter mineralization in sediment of a coastal freshwater lake and response to salinization. Geochim Cosmochim Acta 70:2836-2855

Canfield DE, Jørgensen BB, Fossing H, Glud R and others (1993) Pathways of organic carbon oxidation in three continental margin sediments. Mar Geol 113:27-40

Chen YS, Beveridge MCM, Telfer TC, Roy WJ (2003) Nutrient leaching and settling rate characteristics of the faeces of Atlantic salmon (Salmo salar L.) and the implications for modelling of solid waste dispersion. J Appl Ichthyol 19:114-117

> Cromey CJ, Black KD, Edwards A, Jack IA (1998) Modelling the deposition and biological effects of organic carbon from marine sewage discharges. Estuar Coast Shelf Sci 47:295-308

Cromey CJ, Nickell TD, Black KD (2002a) DEPOMODmodelling the deposition and biological effects of waste solids from marine cage farms. Aquaculture 214:211-239

Cromey CJ, Nickell TD, Black KD, Provost PG, Griffiths CR (2002b) Validation of a fish farm waste resuspension model by use of a particulate tracer discharged from a point source in a coastal environment. Estuaries 25:916-929

Cronin JR, Tyler ID (1980) Organic carbon in a Scottish sea loch. In: Albaiges J (ed) Analytical techniques in environmental chemistry. Pergamon Press, Oxford, p 418-426

> Dale AW, van Cappellen P, Aguilera DR, Regnier P (2008a) Methane efflux from marine sediments in passive and active margins: estimations from bioenergetic reactiontransport simulations. Earth Planet Sci Lett 265:329-344

> Dale AW, Aguilera DR, Regnier P, Fossing H, Knab NJ, Jorgensen BB (2008b) Seasonal dynamics of the depth and rate of anaerobic oxidation of methane in Aarhus Bay (Denmark) sediments. J Mar Res 66:127-155

Dale A, Brüchert V, Alperin M, Regnier P (2009) An integrated sulfur isotope model for Namibian shelf sediments. Geochim Cosmochim Acta 73:1924-1944

Dean R (2004) Biogeochemistry of metals in fish farm sediments. PhD thesis, UHI Millennium Institute, University of Aberdeen

deBruyn AMH, Gobas FAPC (2004) Modelling the diagenetic fate of persistent organic pollutants in organically enriched sediments. Ecol Modell 179:405-416

> Dedieu K, Rabouille C, Gilbert F, Soetaert K and others (2007) Coupling of carbon, nitrogen and oxygen cycles in sedi- 
ments from a Mediterranean lagoon: a seasonal perspective. Mar Ecol Prog Ser 346:45-59

Edwards A, Sharples F (1986) Scottish sea lochs: a catalogue. Scottish Marine Biological Association, Oban

Gribble SD (2001) Robustness in complex systems. In: Proceedings of HotOS-VIII: 8th workshop on hot topics in operating systems, May 20 to 23, 2001, IEEE Computer Society, Elmau/Oberbayern

Hargrave BT, Duplisea DE, Pfeiffer E, Wildish DJ (1993) Seasonal changes in benthic fluxes of dissolved oxygen and ammonium associated with marine cultured Atlantic salmon. Mar Ecol Prog Ser 96:249-257

Hargrave BT, Phillips GA, Doucette LI, White MJ, Milligan TG, Wildish DJ, Cranston RE (1997) Assessing benthic impacts of organic enrichment from marine aquaculture. Water Air Soil Pollut 99:641-650

Harvey SM, Phillips CJ (1994) MAFF Project AE 0511organic waste disposal in the marine environment. Dunstaffnage Marine Laboratory, Oban

- Jourabchi P, van Cappellen P, Regnier P (2005) Quantitative interpretation of $\mathrm{pH}$ distributions in aquatic sediments: a reaction transport modeling approach. Am J Sci 305:919-956

Loh PS, Reeves AD, Overnell J, Harvey SM, Miller AEJ (2002) Assessment of terrigenous organic carbon input to the total organic carbon in sediments from Scottish transitional waters (sea lochs): methodology and preliminary results. Hydrol Earth Syst Sci 6:959-970

Luff R, Wallmann K (2003) Fluid flow, methane fluxes, carbonate precipitation and biogeochemical turnover in gas hydrate-bearing sediments at Hydrate Ridge, Cascadia Margin: numerical modeling and mass balances. Geochim Cosmochim Acta 67:3403-3421

- Meysman F, Middelburg JJ, Herman P, Heip C (2003a) Reactive transport in surface sediments. I. Model complexity and software quality. Comput Geosci 29:291-300

Meysman F, Middelburg JJ, Herman P, Heip C (2003b) Reactive transport in surface sediments. II. Media: an objectoriented problem-solving environment for early diagenesis. Comput Geosci 29:301-318

Morel FMM, Hering JG (1993) Principles and applications of aquatic chemistry. John Wiley and Sons, New York

Naylor RL, Goldburg RJ, Primavera JH, Kautsky N and others (2000) Effect of aquaculture on world fish supplies. Nature 405:1017-1024

Nickell LA, Black KD, Hughes DJ, Overnell J and others (2003) Bioturbation, sediment fluxes and benthic community structure around a salmon cage farm in Loch Creran, Scotland. J Exp Mar Biol Ecol 285/286:221-233

O'Dell JW (ed) (1993) Method 350.1. Determination of ammonia nitrogen by semi-automated colorimetry (Revision 2.0, August 1993). Inorganic Chemistry Branch, Chemistry Research Division, Environmental Monitoring Systems Laboratory, Office of Research and Development, United States Environmental Protection Agency, Cincinnati, OH

Petersen SA, Sutherland TF, Higgs D (2005) Physical and chemical characterization of salmonid feed pellets. Can Data Rep Fish Aquat Sci 1159

Pitta P, Karakassis I, Tsapakis M, Zivanovic S (1998) Natural vs. mariculture induced variability in nutrients and plankton in the eastern Mediterranean. Hydrobiologia 391:179-192

Provost PG (2001) Current speed and meteorological measurements at a proposed fish cage site, Loch Creran. Data report prepared for Hydro Seafood GSP Ltd., Scottish Association for Marine Science, Oban

Regnier P, O'Kane JP, Steefel CI, Vanderborght P (2002) Modeling complex multi-component reactive-transport systems: towards a simulation environment based on the concept of a Knowledge Base. Appl Math Model 26:913-927
Regnier P, Slomp C, Jourabchi P (2003) Reactive transport modeling as a technique for understanding coupled biogeochemical processes in surface and subsurface environments. Neth J Geosci 82:5-18

SEPA (Scottish Environmental Protection Agency) (2005) Regulation and monitoring of marine cage fish farming in Scotland, Issue No. 2.3. Annex H. Issue date: 18 May 2005. Methods for modelling in-feed anti-parasitics and benthic effects. SEPA, Stirling. Available at: http://www.sepa.org. uk/water/water_regulation/regimes/aquaculture/marine_ aquaculture/fish_farm_manual.aspx

Soetaert K, Herman PMJ, Middelburg JJ (1996) Dynamic response of deep-sea sediments to seasonal variations: a model. Limnol Oceanogr 41:1651-1668

Spiteri C, Slomp CP, Regnier P, Meile C, van Cappellen P (2007) Modelling the geochemical fate and transport of wastewater-derived phosphorus in contrasting groundwater systems. J Contam Hydrol 92:87-108

Stewart ARJ, Grant J (2002) Disaggregation rates of extruded salmon feed pellets: influence of physical and biological variables. Aquac Res 33:799-810

Strickland J, Parsons T (1972) A practical handbook of seawater analysis. Bulletin 167, Fisheries Research Board of Canada, Ottawa

Tett P, Wallis A (1978) The general annual cycle of chlorophyll standing crop in Loch Creran. J Ecol 66:227-239

Tett P, Heaney SI, Droop MR (1985) The Redfield ratio and phytoplankton growth rate. J Mar Biol Assoc UK 65:487-504

Thullner M, van Cappellen P, Regnier P (2005) Modeling the impact of microbial activity on redox dynamics in porous media. Geochim Cosmochim Acta 69:5005-5019

Thullner M, Regnier P, Van Cappellen P (2007) Modeling microbially induced carbon degradation in redox stratified subsurface environments: Concepts and open questions. Geomicrobiol J 24:139-155

Tromp TK, van Cappellen P, Key RM (1995) A global model for the early diagenesis of organic carbon and organic phosphorus in marine sediments. Geochim Cosmochim Acta 59:1259-1284

Tung JWT, Tanner PA (2003) Instrumental determination of organic carbon in marine sediments. Mar Chem 80:161-170

van Cappellen P, Gaillard JF (1996) Biogeochemical dynamics in aquatic sediments. In: Lichtner PC, Steefel CI, Oelkers EH (eds) Reactive transport in porous media: general principles and application to geochemical processes. Rev Mineral: 34, Mineralogical Society of America, Washington, DC

van Cappellen P, Wang YF (1996) Cycling of iron and manganese in surface sediments: a general theory for the coupled transport and reaction of carbon, oxygen, nitrogen, sulfur, iron, and manganese. Am J Sci 296:197-243

Wang Y, van Cappellen P (1996) A multicomponent reactive transport model of early diagenesis: application to redox cycling in coastal marine sediments. Geochim Cosmochim Acta 60:2993-3014

Westrich JT, Berner RA (1984) The role of sedimentary organic matter in bacterial sulfate reduction: the G-model tested. Limnol Oceanogr 29:236-249

Wildish DJ, Keizer PD, Wilson AJ, Martin JL (1993) Seasonal changes of dissolved oxygen and plant nutrients in seawater near salmonid net pens in the macrotidal Bay of Fundy. Can J Fish Aquat Sci 50:303-311

Wildish DJ, Akagi HM, Hamilton N, Hargrave BT (1999) A recommended method for monitoring sediments to detect organic enrichment from mariculture in the Bay of Fundy. Can Tech Rep Fish Aquat Sci 2286:1-34

Wildish DJ, Hargrave BT, Pohle G (2001) Cost-effective monitoring of organic enrichment resulting from salmon mariculture. ICES J Mar Sci 58:469-476 
Appendix 1. Reaction network implemented in the early diagenesis model. The network is a simplified version of the one proposed by van Cappellen \& Wang (1996). Reactions 1 to 5 were implemented separately for each organic matter fraction

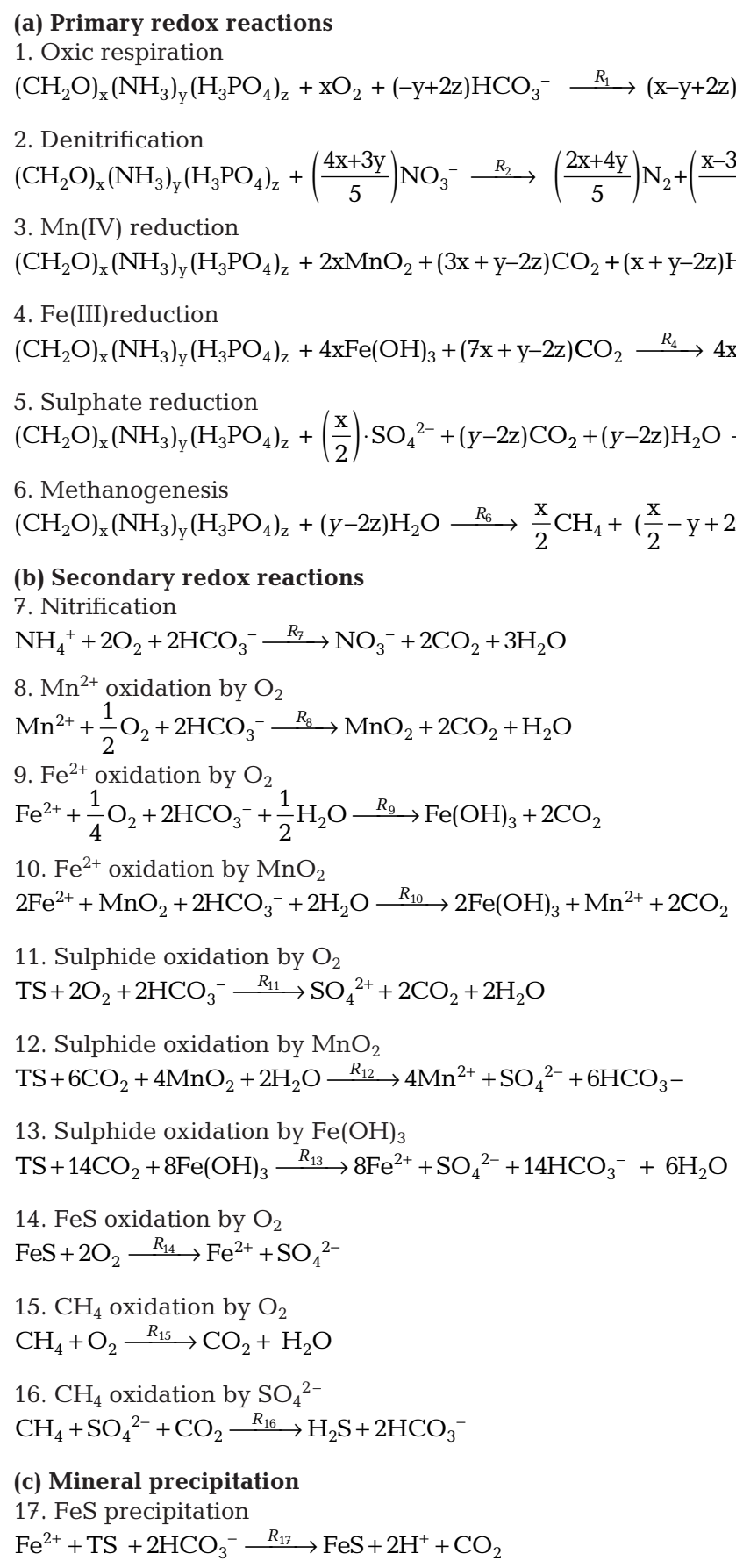


Appendix 2. Rate laws used in the early diagenesis model. Rates refer to the reactions listed in Appendix 1. $f_{i}$ values were computed according to the formulation reported in Aguilera et al. (2005). $\left[\mathrm{H}^{+}\right]$concentration was assumed constant in time and fixed in accordance with the profiles reported by Jourabchi et al. (2005).

$$
\begin{aligned}
& R_{1}=f_{\mathrm{o} 2} \cdot k_{O M \mathrm{k}} \cdot\left[O M_{\mathrm{k}}\right] \cdot k_{a c c} \text { with } k=1,2,3 \\
& R_{2}=f_{\mathrm{NO}_{2}} \cdot k_{O M k} \cdot\left[O M_{k}\right] \cdot k_{a c C} \text {, with } k=1,2,3 \\
& R_{3}=f_{\mathrm{MnO}_{2}} \cdot k_{O M k} \cdot\left[O M_{k}\right] \text {, with } k=1,2,3 \\
& R_{4}=f_{\mathrm{Fe}(\mathrm{OH})_{3}} \cdot k_{O M k} \cdot\left[O M_{k}\right] \text {, with } k=1,2,3 \\
& R_{5}=f_{\mathrm{SO}_{4}} \cdot k_{O M k} \cdot\left[O M_{k}\right] \text {, with } k=1,2,3 \\
& R_{6}=f_{\mathrm{CH}_{4}} \cdot k_{O M k} \cdot\left[O M_{k}\right] \text {, with } k=1,2,3 \\
& R_{7}=k_{7} \cdot\left[\mathrm{NH}_{4}^{+}\right] \cdot\left[\mathrm{O}_{2}\right] \\
& R_{8}=k_{8} \cdot\left[\mathrm{Mn}^{2+}\right] \cdot\left[\mathrm{O}_{2}\right] \\
& R_{9}=k_{9} \cdot\left[\mathrm{Fe}^{2+}\right] \cdot\left[\mathrm{O}_{2}\right] \\
& R_{10}=k_{10} \cdot\left[\mathrm{Fe}^{2+}\right] \cdot\left[\mathrm{MnO}_{2}\right] \\
& R_{11}=k_{11} \cdot[T S] \cdot\left[O_{2}\right] \\
& R_{12}=k_{12} \cdot[T S] \cdot\left[\mathrm{MnO}_{2}\right] \\
& R_{13}=k_{13} \cdot[\mathrm{TS}] \cdot\left[\mathrm{Fe}(\mathrm{OH})_{3}\right] \\
& R_{14}=k_{14} \cdot[\mathrm{FeS}] \cdot\left[\mathrm{O}_{2}\right] \\
& R_{15}=k_{15} \cdot\left[\mathrm{CH}_{4}\right] \cdot\left[\mathrm{O}_{2}\right] \\
& R_{16}=k_{16} \cdot\left[\mathrm{CH}_{4}\right] \cdot\left[\mathrm{SO}_{4}{ }^{2-}\right] \\
& R_{17}=k_{17} \cdot \chi_{17} \cdot\left[\Omega_{\mathrm{FeS}}-1\right] \\
& \Omega_{F e S}=\frac{\left[F^{2+}\right] \cdot[T S]}{\left[H^{+}\right] \cdot K_{F e S}^{\prime}} \quad \begin{array}{ll}
\Omega_{F e S}>1 \chi_{17}=1 \\
\Omega_{F e S} \leq 1 \chi_{17}=0
\end{array}
\end{aligned}
$$

Submitted: December 14, 2007; Accepted: April 21, 2009 Proofs received from author(s): June 26, 2009 